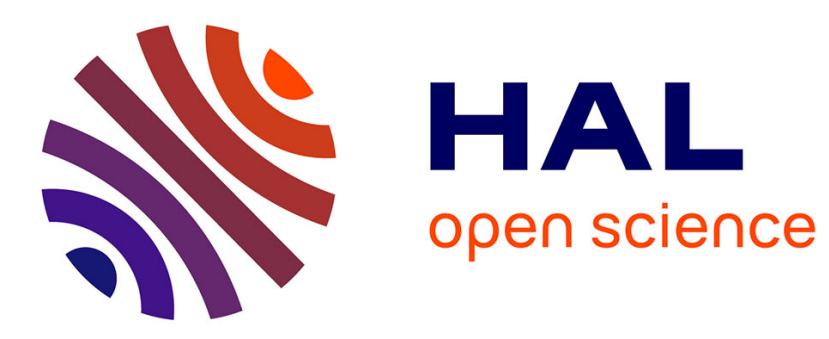

\title{
Possible fluid rock interactions on differentiated asteroids recorded in eucritic meteorites
}

\author{
Jean-Alix J-A Barrat, A. Yamaguchi, T.E. Bunch, Marcel Bohn, Claire \\ Bollinger, Georges Ceuleneer
}

\section{- To cite this version:}

Jean-Alix J-A Barrat, A. Yamaguchi, T.E. Bunch, Marcel Bohn, Claire Bollinger, et al.. Possible fluid rock interactions on differentiated asteroids recorded in eucritic meteorites. Geochimica et Cosmochimica Acta, 2011, 75 (13), pp.3839-3852. insu-00586415

\section{HAL Id: insu-00586415 https://hal-insu.archives-ouvertes.fr/insu-00586415}

Submitted on 15 Apr 2011

HAL is a multi-disciplinary open access archive for the deposit and dissemination of scientific research documents, whether they are published or not. The documents may come from teaching and research institutions in France or abroad, or from public or private research centers.
L'archive ouverte pluridisciplinaire HAL, est destinée au dépôt et à la diffusion de documents scientifiques de niveau recherche, publiés ou non, émanant des établissements d'enseignement et de recherche français ou étrangers, des laboratoires publics ou privés. 


\title{
Possible fluid-rock interactions on differentiated asteroids recorded in eucritic meteorites
}

\author{
by \\ J.A. Barrat ${ }^{1,2}$, A. Yamaguchi ${ }^{3,4}$, T.E. Bunch ${ }^{5}$, M. Bohn ${ }^{1,2}$, \\ C. Bollinger ${ }^{1,2}$, and G. Ceuleneer ${ }^{6}$
}

${ }^{1}$ Université Européenne de Bretagne, France.

${ }^{2}$ CNRS UMR 6538 (Domaines Océaniques), U.B.O.-I.U.E.M., Place Nicolas Copernic, 29280 Plouzané Cedex, France. E-Mail: barrat@ univ-brest.fr.

${ }^{3}$ National Institute of Polar Research, Tachikawa, Tokyo 190-8518, Japan

${ }^{4}$ Department of Polar Science, School of Multidisciplinary Science, Graduate University for Advanced Sciences, Tokyo 190-8518, Japan.

${ }^{5}$ Department of Geology, Northern Arizona University, Flagstaff, Arizona.

${ }^{6}$ C.N.R.S., Université Paul Sabatier - Observatoire Midi-Pyrénées, 14, av. Édouard Belin, 31400 Toulouse, France

Submitted to GCA, 10/11/10, accepted 4/13/11 


\begin{abstract}
The eucritic meteorites are basaltic rocks that originate from the upper part of the crust of some small bodies as exemplified possibly by asteroid 4-Vesta. A few eucrites appear to have been modified by different degrees of a late stage alteration process that caused significant variations in mineralogy. Three distinct alteration stages are identified: 1/ Fe-enrichment along the cracks that cross cut the pyroxene crystals ("Fe-metasomatism"); secondary olivine and minute amounts of troilite are found only occasionally in cracks at this stage; 2/ deposits of Fe-rich olivine $\left(\mathrm{Fa}_{64-86}\right)$ and minor amounts of troilite are frequent inside the cracks; sporadic secondary Ca-rich plagioclase $\left(\mathrm{An}_{97-98}\right)$ is associated with the fayalitic olivine; $3 /$ at this stage, the Fe-enrichment of the pyroxene is accompanied by a marked Al-depletion; moreover, secondary Ca-rich plagioclase is more frequent and partly fills some cracks or rims of the primary plagioclase crystals. The composition of the secondary phases on one hand, the lack of incompatible trace element enrichment in the metasomatized pyroxenes on the other hand, rule out a silicate melt as the metasomatic agent. Although no hydrous phase has been yet identified in the studied samples, aqueous fluids are plausible candidates for explaining the deposits of ferroan olivine and anorthitic plagioclase inside the fractures of the studied unequilibrated eucrites.
\end{abstract}




\section{Introduction}

Eucrite meteorites are igneous rocks, basaltic or gabbroic in composition, that sample the oldest known basic crusts, formed about $4.5 \mathrm{Ga}$ ago at the surface of small planetary bodies. It is generally agreed that most of the eucrites originated from the same parent body, probably the asteroid 4-Vesta (McCord et al., 1970; Consolmagno and Drake, 1977; Hewins and Newsom, 1988), also a handful of them derived clearly from distinct bodies (Yamaguchi et al., 2002; Scott et al., 2009; Bland et al., 2009; Gounelle et al., 2009).

Most of the eucrites have recorded complex post-crystallization histories (e.g., Metzler et al., 1995; Yamaguchi et al., 1996, 2001). The surfaces of their parent bodies were extensively brecciated and sometimes melted by meteorite impacts. Therefore, eucrites are usually breccias containing one or more types of clasts. Unbrecciated eucrites such as the basaltic eucrite Agoult and the cumulate eucrites Moore County and Serra de Mage, are rare. Most of these rocks have experienced extensive thermal annealing that produced recrystallization textures and caused exsolution and inversion of pyroxenes (e.g., Takeda and Graham, 1991; Metzler et al., 1995; Yamaguchi et al., 1996, 2009; Mayne et al., 2009). Rarely have "unmetamorphosed" (or unequilibrated) lithologies been preserved, and these are mainly small-size objects (e.g., Bluewing 001, Warren and Gessler, 2001) or fragments in some polymict eucrites (e.g., Yamato (Y-) 75011, Takeda et al., 1994, and Macibini, Buchanan et al., 2000).

Post-crystallization processes sustained by eucrites are not limited to thermal annealing and brecciation. A veinlet made of secondary quartz has been described in Serra de Mage, and was ascribed to the circulation of water in the crust of its parent body (Treiman et al., 2004). Evidence of fluid-rock interactions in these lithologies is not restricted to this single meteorite. Some of the unequilibrated lithologies preserve a marked Fe-enrichment along the fractures that go through the pyroxenes ("Fe-metasomatism", Mittlefehldt and 
Lindstrom, 1997), and occasionally display Fe-rich olivine veins that clearly postdate the magmatic history of the rocks (e.g., Takeda et al., 1983, 1994; Warren, 2002; Roszjar et al., 2009). In this study, we have selected a series of eucrites that display evidence of $\mathrm{Fe}$ enrichment along cracks and fayalitic olivine veinlets, in order to describe precisely these mineralogical changes and to discuss their origin, and their implications for the early history of their parent bodies

\section{Samples and analytical techniques}

Among the numerous polished sections of eucrites we have examined during the last fifteen years, only some of them exhibit unambiguous evidences of fluid-rock interactions. Based on our previous observations, we have selected for a detailed study, the polished sections prepared from six distinct eucrites. Samples of the two Yamato eucrites, Y-75011 and Y-82202, were supplied by the National Institute of Polar Research (Tokyo) (NIPR), Sioux County by University of New Mexico, Pasamonte by the Hawaii Institute of Geophysics and Planetology, University of Hawaii at Manoa (courtesy of E.R.D. Scott), Northwest Africa (NWA) 049 by Bruno and Carine Fectay (la Mémoire de la Terre) and NWA 2061 by Northern Arizona University.

Polished sections of these eucrites were examined using an optical microscope and a scanning electron microscope (SEM) (JSM5900LV) equipped with an energy dispersive spectrometer (EDS) (Oxford Link-ISIS) at NIPR. The major-element compositions of the phases were determined by electron microprobe analysis using a Cameca SX100 at Ifremer, Plouzané, or a JEOL JXA8200 at NIPR. About 3000 analyses were obtained during the course of this study. All analyses used wavelength dispersive spectrometers at $15 \mathrm{kV}$ accelerating voltage, 10-30 nA beam current. Minerals and metal standards were used for calibration. 
Trace element abundances of the NWA 049 pyroxenes were determined by laser ablation inductively coupled plasma mass spectrometry (LA-ICP-MS) at the Institut Universitaire Européen de la Mer, Plouzané. The analyses were performed in He atmosphere using an Excimer (193 nm wavelength) laser ablation system (Geolas Pro102), connected to a Thermo Element 2 spectrometer. Analytical and data reduction procedures followed those described by Barrat et al. (2009). Concentrations were determined on individual spots using a $60 \mu \mathrm{m}$-diameter laser beam. Results were normalized to $\mathrm{CaO}$ abundances measured by electron microprobe as an internal standard to account for variable ablation yield.

\section{Petrography}

The main petrographical features, especially the compositions of the primary phases (plagioclases and pyroxenes) of the eucrites that we have selected for this study, have been described in previous studies, and are summarized together with our observations in Table 1. The phase compositions are listed in Table 2. Here, we will first describe the secondary phases displayed by the unequilibrated eucrites we have selected, which allow us to characterize three successive stages of alteration. Afterward, we will show that some equilibrated eucrites have possibly undergone the same secondary processes, as exemplified by Sioux County.

\subsection{Unequilibrated eucrites}

-Stage 1: Fe-enrichment along the fractures in pyroxenes, the case of Pasamonte

Pasamonte is an exceptional polymict eucrite. Wiechert et al. (2004), Greenwood et al. (2005) and Scott et al. (2009) have repeatedly shown that its oxygen isotopic composition distinguishes it from the typical HED meteorites, suggesting a distinct parent body for this 
meteorite. However, it is actually one of the best examples of eucrites displaying the "stage1 " features.

The major and trace element compositions of the Pasamonte pyroxenes have been previously determined by Takeda et al. (1978), Miyamoto et al. (1985), Metzler et al. (1985), Pun and Papike (1996), Hsu and Crozaz (1996), Herd et al. (2004) and Schwartz and McCallum (2006). The polished thin section we have studied, was prepared from a large unequilibrated subophitic clast (Fig. 1). In perfect agreement with previous studies, the pyroxenes are highly heterogeneous (Fig. 2 and Table 2). Firstly, they display igneous compositional zoning, compositions range from $\mathrm{Mg}_{66} \mathrm{Ca}_{5} \mathrm{Fe}_{29}$ in the cores to $\mathrm{Mg}_{37} \mathrm{Ca}_{11} \mathrm{Fe}_{52}$ in the rims that abut against plagioclase. More Ca-rich compositions (up to $\mathrm{Mg}_{29} \mathrm{Ca}_{44} \mathrm{Fe}_{27}$ ) have been measured in the rims adjoining the mesostasis. These compositions are similar to the values reported by Takeda et al. (1978) or Miyamoto et al. (1985). Secondly, the pyroxenes typically display annealed cracks. Iron is enriched along these cracks in the Fe-rich pyroxenes (Herd et al., 2004), which produce a network of bands about $10 \mu \mathrm{m}$ thick (but of course their apparent thicknesses are often larger when the fractures are not perpendicular to the section), as shown on back scattered electron (BSE) images (e.g., Fig. 1) or on chemical maps (supplementary Figure 1). In some areas, Fe-rich olivine $\left(\mathrm{Fa}_{64-70}\right)$ crystallized within these cracks. Iron-enrichment in the margins of the host pyroxene adjacent to the veinlets is limited to the outer $5 \mu \mathrm{m}$ (Fig. 3).

The Fe-enrichment is the main chemical change that can be detected in the pyroxenes. The Fe/Mn ratios of the modified pyroxenes are undistinguishable to those of the primary pyroxenes, and indicate that Mn shared the same behavior as Fe during the process (notice that our analytical conditions do not allow to detect small variations $(<10 \%)$ of the Fe/Mn ratios). Other minor elements analyzed during the course of the study ( $\mathrm{Ti}, \mathrm{Al}, \mathrm{Cr}$ ) are unaffected, as illustrated by the constancy of the Ti/Al ratios (Fig. 2). 
Interestingly, secondary Fe-enrichments are apparently lacking in the sample studied by Takeda et al. (1978), or in the pyroxene analyzed in detail by Hsu and Crozaz (1996) (see their Figure 7a). Fe-enrichment has been seen by Miyamoto et al. (1985) only in some pyroxene clasts found in the matrix (their type-3 zoning), and is obvious in the sub-ophitic clast studied by Herd et al. (2004). Thus not all clasts found in Pasamonte are affected in the same manner by the secondary process responsible of the Fe-enrichment.

-Stage 2: Development of fayalitic olivine veinlets in pyroxenes of NWA 2061, Y-75011 and Y82202

NWA 2061, Y-75011 and Y-82202 are among the least metamorphosed eucrites yet described (e.g., Yamaguchi and Takeda, 1992; Takeda et al., 1994; Buchanan et al., 2005). The samples we have selected exhibit subophitic to porphyritic textures with pyroxenes displaying striking magmatic zonings (Table 1, Figs. 4-6). Similar to Pasamonte, their pyroxenes exhibit cracks displaying a similar Fe-enrichment, but these cracks are often filled by fayalitic olivine (from $\mathrm{Fa}_{70}$ in $\mathrm{Y}-75011$ to $\mathrm{Fa}_{86}$ in $\mathrm{Y}-82202$ ) with minor amounts of troilite. The Fe-enrichment in pyroxenes affects only the first $5 \mu \mathrm{m}$ abutting the cracks or the olivine veinlets (Fig. 3). As in Pasamonte, the altered Fe-rich pyroxene margins display the same $\mathrm{Fe} / \mathrm{Mn}$ and $\mathrm{Al} / \mathrm{Ti}$ ratios found in the pristine interiors (e.g., exemplified by NWA 2061, Fig. 7).

In NWA 2061 and Y-75011, very small grains $(<10 \mu \mathrm{m})$ of plagioclase are sometimes associated with the olivine veinlets, and are more frequently found in the veins abutting the plagioclase phenocrysts (Fig. 4). Compositions of these secondary feldspars are distinct with primary plagioclases (Table 2, Fig. 8) and consist of nearly pure anorthite (An $\left.{ }_{97-99}\right)$, with minor amounts of $\mathrm{FeO}(0.9-1.6 \mathrm{wt} \%)$.

-Stage 3: Development of Al-depleted, Fe-rich pyroxenes in NWA 049 
NWA 049 is a main-group eucrite that contains mostly unequilibrated subophitic clasts and less abundant fragments of equilibrated pyroxenes (Beck et al., 2001; Barrat et al., 2003). The unequilibrated clasts resemble those in Y-75011, but display some important differences (Fig. 9). Firstly, the most Ca-rich areas of the pyroxenes contain augite exsolution, some of which can be resolved by electron microprobe analyses. We note that the intermediate compositions between low- and high-Ca pyroxenes measured in these areas are artifacts due to EPMA beam overlap during analysis (Fig. 5). Secondly, the pyroxenes display numerous crisscross cracks and fayalitic veins $\left(\mathrm{Fa}_{76-80}\right)$. The Fe-enrichment sustained by the pyroxenes is not restricted to just the outer $5 \mu \mathrm{m}$ adjacent to the veinlets observed in the Y75011 pyroxenes, but extends inward to at least $50 \mu \mathrm{m}$ (Fig. 10). Consequently, the pristine pyroxenes occur generally as remnant cores displaying the most Mg-rich compositions $\left(\mathrm{Mg}_{65}\right.$ ${ }_{57} \mathrm{Ca}_{4-7} \mathrm{Fe}_{30-37}$, Fig. 5). Furthermore, secondary anorthitic plagioclases $\left(\mathrm{An}_{97-98}, \mathrm{FeO}=0.59-\right.$ $1.44 \mathrm{wt} \%$, Table 2 and Fig. 8) are more common in this eucrite, and are frequently found as veinlets associated with the fayalitic olivine (Fig. 9), or as discontinuous rims on the primary plagioclase crystals (supplementary materials, Fig. 2). Troilite grains are commonly associated with anorthitic plagioclases and fayalitic olivine.

Compared to the primary (magmatic) pyroxenes, the secondary Fe-rich pyroxenes display striking chemical changes, which are obvious in the compositional profile performed across three parallel cracks (Fig. 10). These pyroxenes are not only strongly Fe-enriched, but are also Al-depleted, and display $\mathrm{Al}_{2} \mathrm{O}_{3}$ abundances mostly below $0.5 \mathrm{wt} \%$. These values are extremely unusual for unequilibrated pigeonites in eucrites. In the case of magmatic zoning, a marked Al-depletion is often observed and indicates the onset of plagioclase crystallization in the system, $\mathrm{Al}_{2} \mathrm{O}_{3}$ abundances are always in the level of $1 \mathrm{wt} \%$ (Fig. 6). The unusual behavior of $\mathrm{Al}$ in the Fe-enriched pyroxenes is well shown in the $\mathrm{Ti} / \mathrm{Al}$ vs. $\mathrm{Mg} /(\mathrm{Mg}+\mathrm{Fe})$ plot (Fig. 7), where two types of Fe-rich pyroxenes can be distinguished. Firstly, pyroxenes with 
$\mathrm{Mg} /(\mathrm{Mg}+\mathrm{Fe})$ ratios that range from about 0.6 to 0.45 , display the same $\mathrm{Ti} / \mathrm{Al}$ ratios as the primary pyroxenes. These pyroxenes are equivalent to the Fe-rich pyroxenes previously observed in stages 1 and 2, and are found rimming the primary pyroxenes. Secondly, the Aldepleted Fe-rich pyroxenes with $\mathrm{Mg} /(\mathrm{Mg}+\mathrm{Fe})$ ratios ranging from about 0.45 to 0.35 , display a wide range of Ti/Al ratios from nearly 0 to 0.7 (atomic). Both types of Fe-rich pyroxenes display the same $\mathrm{Fe} / \mathrm{Mn}$ ratios as the primary pyroxenes. Notice that the $\mathrm{Cr}$ abundances in the NWA 049 pyroxenes are erratic (Fig. 10), and could be partly explained by the segregation of tiny chromite grains. This contrasts with the behavior of $\mathrm{Cr}$ in other unequilibrated eucrites (as exemplified in Fig. 6 for NWA 2061), where the magmatic pyroxenes are better preserved.

A few areas of Fe-rich pyroxenes in NWA 049 are sufficiently large to be analyzed for trace elements (Table 3). We have analyzed 2 pristine $\mathrm{Mg}$-rich and $3 \mathrm{Fe}$-rich areas. Although a significant spread of the abundances is obtained (Fig. 11), the results for Fe-rich pyroxenes are similar to those obtained for the pristine ones: the REE abundances are in the range of the values previously obtained for pyroxenes from unequilibrated eucrites (Pun and Papike, 1996), and the REE patterns obtained for Fe-rich pyroxenes display basically the same shapes and $\mathrm{Eu}$ anomalies as those of the primary pyroxenes.

\subsection{Equilibrated eucrites}

Despite a careful search, Fe-enrichments along cracks in pyroxenes from equilibrated eucrites have not yet been observed. Nevertheless, in pyroxene clasts from the polymict eucrite Sioux County, we have discovered olivine veins with chemical composition in the range of those found in the unequilibrated eucrites (Fa $\mathrm{Fa}_{74-76}$, Table 2 and Figs. 12a, b).

The section we studied (UNM621) is highly brecciated, contains basaltic and gabbroic clasts (up to $5.4 \mathrm{~mm}$ ) with abundant fragments of pyroxenes and plagioclase. Thin veins $(\sim 10-$ $50 \mu \mathrm{m}$ thick) of low-Ca pyroxene and fayalite with minor plagioclase and silica minerals are 
found in several pyroxenes. In some cases, there are large, irregular areas of low-Ca pyroxene in contact with areas with densely exsolved pyroxenes. It is not clear how these areas are related to the thin low-Ca pyroxene veins. We could not find any Fe-enrichment of the host pyroxenes along these veins like those in unequilibrated eucrites (see above). In some cases, augite lamellae are denser along the contact with the low-Ca pyroxene veins, but such features are lacking along the fayalite veins. Compositions of plagioclase grains (a few tens $\mu \mathrm{m}$ ) $\left(A n_{89.8-97.2)}\right.$ associated with the veins are generally more calcic than those of normal plagioclase $\left(\mathrm{An}_{71.9-93.7}\right)$. Unlike unequilibrated eucrites we studied, there is no clear compositional gap between plagioclase inclusions in pyroxenes and large plagioclase crystals (Fig. 12c). The highest An-values are significantly higher than compositional range of plagioclase in basaltic eucrites (Delaney et al., 1984; Mittlefehldt et al., 1998; Mayne et al., 2009) and similar to those of secondary plagioclase in unequilibrated eucrites (Fig. 8). Thus, the Sioux County clasts studied here have probably contained secondary plagioclase grains, whose compositions equilibrated with igneous plagioclase by thermal metamorphism. This observation indicates that some equilibrated eucrites have undergone the same secondary processes as the unequilibrated ones before metamorphic events.

\section{Origin of the secondary phases in eucrites.}

The Fe-enrichments shown by the pyroxenes along some cracks, and the development of fayalitic olivine veins and anorthitic plagioclase in eucrites are unquestionably preterrestrial features and formed on their parent body (ies): two of the studied samples are falls (Pasamonte and Sioux County), and in the case of the two Saharan finds (NWA 049 and NWA 2061), the terrestrial weathering (calcite veins) clearly postdates the cracks filled with fayalitic olivine (e.g., Fig. 9). 
Fayalitic olivine veins were first described by Takeda et al. $(1983,1994)$ in Y-75011. These authors have proposed that during a short-duration reheating event (presumably shock), the late-stage phases contained by the mesostasis were partly remelted, and the resulting Ferich melts were directly injected into the fractures. A similar explanation has been suggested for the olivine veins $\left(\mathrm{Fa}_{75}\right)$ exhibited by NWA 1000, a strongly-shocked eucrite whose plagioclase has been partly converted to maskelynite (Warren, 2002). Although eucritic breccias have suffered severe impact processing, this explanation is unlikely for many reasons:

- In all the samples we have examined, the mesostasis shows neither evidence of remelting, nor evidence of connection with the olivine veins.

- Reheating experiments of a eucrite have shown that melts produced by the remelting of the mesostasis are highly mobile and display marked enrichments in $\mathrm{Ti}$ and $\mathrm{P}$ (Yamaguchi and Mikouchi, 2005). Furthermore, melts generated by the remelting of mesostasis-rich areas are characterized by very high incompatible trace element abundances such as REEs or Th (e.g., Barrat et al., 2007). Thus, if shock melting were involved, the Fe-rich pyroxenes observed along the cracks should display distinctive Ti/Al ratios, and anomalously high REE abundances. Instead, in all the "stage 1" and "stage 2" samples, Fe-rich pyroxenes located close to the cracks show the same Ti/Al ratios as the pristine pyroxenes. In the case of NWA 049, the unusual high Ti/Al ratios displayed by some of the Fe-rich pyroxenes are not explained by high Ti abundances but by very low Al concentrations. Moreover, the REE abundances of the secondary pyroxenes and primary, $\mathrm{Mg}$-rich pyroxenes from this sample are not fundamentally different (Fig. 11), and rule out the infiltration into the cracks of REE-rich partially melted mesostasis. 
- Mesostasis areas display among the most $\mathrm{Na}$ and K-rich plagioclases found in the unequilibrated eucrites (e.g., Takeda et al., 1994). Therefore, melts formed by remelting of the mesostasis are unable to crystallize the anorthitic plagioclase grains associated with the fayalitic olivine veins.

- If the fayalitic veins originated from the remelting of mesostasis, similar veins should be quite frequent in the few known shocked basaltic or gabbroic meteorites from the Moon, which, like unequilibrated eucrites, are made of unequilibrated pyroxenes, plagioclases (often maskelynitized), and display similar mesostasis-rich areas. To date, Fe-enrichment along cracks in pyroxenes has never been observed in these meteorites (see for a review, the Lunar meteorite compendium by K. Righter, http://curator.jsc.nasa.gov/antmet/lmc/index.cfm). Only one possible fayalitic veinlet has been observed in a basaltic clast from MET 01210 (see Fig. 3c in Arai et al., 2010), and is not associated with a high degree of shock nor remelting of the mesostasis. It suggests that some lunar rocks could have suffered the same secondary processes as the eucrites (see below).

Consequently, the fayalitic olivine veins are unlikely the result of injection into the cracks of melts formed by the remelting of the mesostasis. As a possible alternative, an enigmatic $\mathrm{Fe}-$ rich silicate melt may have entered into the opened fractures. Such an evolved melt should display high incompatible trace element abundances, and should be more sodic than typical eucrites. The lack of incompatible element enrichment in the secondary Fe-rich pyroxenes in NWA 049, and the occurrence of nearly pure anorthite with olivine veins demonstrate that this option is not reasonable.

More likely, the Fe-enrichments displayed by the interiors of the fractured pyroxenes require the involvement of a metasomatic agent, probably a fluid or a vapor (Mittlefehldt and 
Lindstrom, 1997; Herd et al., 2004; Schwartz and McCallum, 2005). Because the fayalitic olivine and troilite that fill the cracks were precipitated from this fluid, it should have mobilized and supplied abundant elements to the secondary phases. These include not only $\mathrm{Fe}$, but $\mathrm{Si}, \mathrm{Mg}, \mathrm{Mn}, \mathrm{S}$, and also $\mathrm{Ca}$ and $\mathrm{Al}$ in at least three samples containing anorthitic plagioclase (Y-75011, NWA 049 and NWA 2061). Furthermore, the metasomatic agent failed to totally overprint the igneous zoning recorded by the pyroxenes. This outcome implies a process that was efficient in terms of cation transport, but probably of short duration.

A dry vapor phase can coexist with solids at high temperatures $\left(>1300{ }^{\circ} \mathrm{C}\right)$ and could be a transport agent for $\mathrm{Fe}, \mathrm{Mg}$ and $\mathrm{Si}$ (Dohmen et al., 1998). From these experimental results, Schwartz and McCallum (2005) have proposed that a vapor in equilibrium with eucrites could have been an ubiquitous metasomatic agent in the upper crust of their parent body (ies), and could have been responsible for the late chemical changes displayed by the pyroxenes in Pasamonte. Although tempting, we do not favor this hypothesis because the experimental results obtained by Dohmen et al. (1998) are inconsistent with the physical/chemical environment of the upper crust of a differentiated asteroid or a small planetary body.

Magmatic gases emitted during eucritic eruptions were probably analogous to gases emitted by lunar mare volcanism, which are assumed to be dominated by $\mathrm{CO}, \mathrm{CO}_{2}, \mathrm{COS}$, $\mathrm{CS}_{2}$, and $\mathrm{S}_{2}$ (e.g., Fegley, 1991; Fogel and Rutherford, 1995), with possibly noticeable amounts of water (Saal et al., 2008). Eucrites often contain free silica (typically tridymite) and sometimes a small amount of metal (e.g., Delaney et al., 1984). CO could react with metallic $\mathrm{Fe}$ and silica, and form fayalite $\left(2 \mathrm{Fe}^{0}(\mathrm{~s})+\mathrm{SiO}_{2}(\mathrm{~s})+2 \mathrm{CO}(\mathrm{g})=\mathrm{Fe}_{2} \mathrm{SiO}_{4}(\mathrm{~s})+2 \mathrm{C}(\mathrm{s})\right.$; Brearley, 1990), but this reaction is unlikely: 1/ olivine in veins contains a significant proportion of the forsterite endmember that cannot be accounted for by this reaction alone; 2/ eucrites display only a limited amount of metal, and the ferroan olivine veins are too voluminous in some clasts (e.g., NWA 049 or Y-75011) to be the result of this reaction; 3/ no 
$\mathrm{C}$ phase has been detected in the studied clasts. Moreover, cryptic or modal metasomatism induced by carbonate-rich fluids are well known in terrestrial systems. The fingerprints of these fluids are exemplified by a high mobility of some elements and deposition of carbonate phases (e.g., Fourcade et al., 1996). If $\mathrm{CO}-\mathrm{CO}_{2}$ rich fluids have circulated into eucrites, $\mathrm{Fe}-$ rich carbonates (or their decomposition products) should be expected. Instead, such phases are lacking in the veins. Moreover, the silica solubility in $\mathrm{CO}-\mathrm{CO}_{2}$ fluids is negligible (e.g., Newton and Manning, 2000; Treiman et al., 2004), ruling out this possibility.

Alternatively, dry vapors could be generated during crater formation, and could explain unusual chemical features of some impactites (e.g., K-enrichment) via volatilization/condensation processes (Yakovlev and Parfenova, 1980). If involved, such dry vapors should conceivably be an efficient transport agent for the most volatile elements, particularly $\mathrm{S}$ and the alkalis. No $\mathrm{K}$ or $\mathrm{Na}$ enrichment has been detected in or near cracks of the studied eucrites. Of course, troilite grains occur in the cracks, but are not particularly abundant. Thus, $\mathrm{S}$ was definitely present, but not as a main component in the metasomatic agent.

Could the metasomatic fluid be aqueous? Hydrothermal fayalitic olivines (e.g., Rasmussen et al., 1998), anorthitic plagioclases (e.g., Python et al., 2007; Mora et al., 2009) and low-Al pyroxenes (Morishita et al., 2003) are known on Earth. Secondary fayalitic olivine has been described in many carbonaceous and in some unequilibrated ordinary chondrites (e.g., Peck and Wood, 1987; Wasson and Krot, 1994; Krot et al., 1995, 2000; Jogo et al., 2009). Two types of models have been suggested for its origin: fayalite in chondrites could be seen as direct condensates of a high-temperature nebular gas (e.g., Hua and Buseck, 1995), or alternatively, it could have been deposited by low-temperature aqueous solution (e.g., Krot et al., 1998, 2000; Jogo et al., 2009). This second model is strongly supported by Mn-Cr ages of the fayalite, which indicate that its formation belongs to a post-accretion alteration event of 
the parent body and by thermodynamic constraints (e.g., Hutcheon et al., 1998; Zolotov et al., 2006; see Zolensky et al. (2008) for a detailed synthesis). Textural relationships demonstrate that fayalite and Fe-rich olivine have formed at the expense of metal and magnetite from possibly the following reactions (e.g., Zolotov et al., 2006):

$$
\begin{aligned}
& 2 \mathrm{Fe}^{0}+2 \mathrm{H}_{2} \mathrm{O}(\mathrm{g}, \mathrm{l})+\mathrm{SiO}_{2}(\mathrm{aq}, \mathrm{s})=\mathrm{Fe}_{2} \mathrm{SiO}_{4}(\mathrm{~s})+2 \mathrm{H}_{2}(\mathrm{~g}) \\
& 2 \mathrm{Fe}_{3} \mathrm{O}_{4}+3 \mathrm{SiO}_{2}(\mathrm{aq}, \mathrm{s})+\mathrm{H}_{2}(\mathrm{~g}, \mathrm{aq})=2 \mathrm{Fe}_{2} \mathrm{SiO}_{4}(\mathrm{~s})+2 \mathrm{Fe}^{0}+2 \mathrm{H}_{2} \mathrm{O}
\end{aligned}
$$

Although it is extremely tempting to consider that fayalitic veins found in eucrites and chondrites could be the result of the same kind of secondary processes, the situations are clearly different. Firstly, magnetite is unknown in eucrites. Secondly, despite a careful examination of the sections, none of the eucrites we have examined display evidence of growth of secondary olivine to the detriment of a primary phase, nor hydrous secondary phases. The same problem arises for the origin of the secondary anorthitic plagioclase. This phase could be the result of dissolution/redeposition processes from primary plagioclase, but textural evidence are lacking or at best ambiguous. Alternatively, one may suggest that $\mathrm{Al}$ and possibly Ca were liberated during the formation of secondary low-Al pyroxenes in NWA 049, and could explain the crystallization of nearly pure anorthite in the fractures. This explanation is again not satisfactory because it cannot account for the occurrence of secondary anorthitic grains in NWA 2061 and Y-75011. These observations could indicate either that some of the fingerprints of the fluid-minerals interactions have been subsequently erased during the thermal history of the unequilibrated eucrites, or that the systems were largely open (i.e., most of the elements deposited inside the cracks were introduced into the system). At present, a full evaluation of the thermodynamic conditions of the secondary processes suffered by the eucrites is not possible.

Although no hydrous phase has been identified in the studied samples, aqueous fluids seem plausible candidates for explaining the deposits of ferroan olivine and anorthitic 
plagioclase inside the fractures. Indeed, at very high temperatures (i.e., temperatures higher than the stability fields of the hydrous phases), aqueous fluids are capable to generate nominally dry secondary phases (e.g., McCollom and Shock, 1998; Python et al., 2007). If the involved fluids in the studied samples were really aqueous, such physical conditions could explain the lack of hydrous phases.

The involvement of aqueous fluids has been invoked for explaining a quartz veinlet displayed by the Serra de Magé cumulate eucrite (Treiman et al., 2004), or some Fe enrichments in low-Ca pyroxenes from a couple of howardites (Mittlefehldt et al., 2011). Episodic aqueous fluids could have been brought to the surface of dry bodies (e.g., the Moon, 4-Vesta) by cometary impacts (Treiman et al., 2004; Greenwood et al., 2011). At present, we can just speculate on the possibility of hydrothermal processes on 4-Vesta. If the crust has been locally weathered by aqueous fluids, hydrated and/or hydroxylated phases should have been deposited at least locally in other parts of the hydrothermal system(s) (i.e., depending of the temperature of the fluids). Interestingly, such phases have been inferred in some areas of Vesta by Earth-based observations (Hasegawa et al., 2003; Prokof'eva-Mikhailovskaya et al., 2008). In September 2007, the Dawn spacecraft was launched to the asteroid belt and will begin studying Vesta in 2011 (Russell et al. 2007). The planned remote sensing studies should allow for confirmation of previous Earth-based or Hubble Space Telescope observations, and may potentially pinpoint hydrothermally altered regions.

\section{Conclusions}

The compositions displayed by the pyroxenes in unequilibrated eucrites, cannot be interpreted solely as the result of primary fractionation of a melt. The Fe-enrichments observed along the fractures, the deposition of ferroan olivine, troilite, and anorthitic plagioclase inside some of them, are unlikely be the result of shock as previously proposed 
(e.g., Takeda et al., 1983, 1994; Warren, 2002). Instead, they are more likely the result of metasomatism. Our results rule out an infiltrated silicate melt, but point to a vapor phase in agreement with some previous studies (Mittlefehldt and Lindstrom, 1997; Schwartz and McCallum, 2005). Not all the eucrites are affected in the same manner by the metasomatic agent, and three distinct alteration stages are identified. Pasamonte is our least metasomatized sample, and displays chiefly Fe-enrichment along the cracks that cross cut the pyroxene crystals. To the opposite, NWA 049 appears to be the most modified sample. This eucrite displays abundant deposits of Fe-rich olivine, frequent veinlets of anorthitic plagioclase, and the Fe-enrichment along cracks in pyroxenes are accompanied by a marked Al-depletion. All the other samples examined here (NWA 2061, Y-75011, Y-82202), and most of the other metasomatized samples described in the literature (Macibini (Buchanan et al., 2000), NWA 1000 (Warren, 2002), and possibly NWA 5073 (Roszjar et al., 2009)), are intermediate between these two extremes. Aqueous fluids seem at present the most plausible candidates for explaining the deposits of the secondary silicates inside the fractures of the studied unequilibrated eucrites.

\section{Acknowledgements}

Samples were kindly provided by the National Institute for Polar Research (Tokyo), University of New Mexico, Ed Scott (HIGP, University of Hawaii), Northern Arizona University, and Bruno and Carine Fectay (La Mémoire de la Terre). We thank Sasha Krot for the editorial handling, Jeff Taylor, and an anonymous reviewer for their constructive comments, David Mittlefehldt for an unofficial review, Michel Fialin (UPMC) for the analyses of the secondary plagioclases from NWA 2061, and Pascale Barrat for her help. We gratefully acknowledge the Programme National de Planétologie (INSU) for financial support. This research has made use of NASA's Astrophysics Data System Abstract Service. 


\section{References}

Arai T., Hawke B.R., Giguere T.A., Misawa K., Miyamoto M., Kojima H. (2010) Antarctic lunar meteorites Yamato-793169, Asuka-881757, MIL 05035, and MET 01210 (YAMM). Lunch pairing and possible cryptomare origin. Geochim. Cosmochim. Acta 74, 2231-2248.

Barrat J.A., Jambon A., Bohn M., Blichert-Toft J., Sautter V., Göpel C., Gillet Ph., Boudouma O., Keller F. (2003) Petrology and geochemistry of the unbrecciatted achondrite North West Africa 1240 (NWA 1240): an HED parent body impact melt. Geochim. Cosmochim. Acta 67, 3959-3970.

Barrat J.A., Yamaguchi A., Greenwood R.C., Bohn M., Cotton J., Benoit M., Franchi I.A. (2007) The Stannern trend eucrites: Contamination of Main-Group eucritic magmas by crustal partial melts. Geochim. Cosmochim. Acta 71, 4108-4124.

Barrat J.A., Yamaguchi A., Greenwood R.C., Bollinger C.,. Bohn M, Franchi I.A. (2009) Trace element geochemistry of K-rich impact spherules from howardites. Geochim. Cosmochim. Acta 73, 5944-5958.

Beck P., Barrat J.A., Jambon A., Gillet Ph., Blichert-Toft J., Lesourd M. (2001) The polymict eucrite North West Africa 049. Meteoritics Planetary Sci. 36, 9, A17 (abstract).

Bland P.A. et al. (2009) An anomalous basaltic meteorite from the innermost main belt. Science 325, 1525-1527.

Brearley A.J. (1990) Carbon-rich aggregates in type 3 ordinary chondrites: Characterization, origins, and thermal history, Geochim. Cosmochim. Acta 54, 831-850, 1990.

Buchanan P.C., Lindstrom D.J., Mittlefehldt D.W., Koeberl C., Reimold W.U. (2000) The South African polymict eucrite Macibini. Meteoritics Planet. Sci. 35, 1321-1331.

Buchanan P.C., Noguchi T., Bogard D.D., Ebihara M., Katayama I. (2005) Glass veins in the unequilibrated eucrite Yamato 82202. Geochim. Cosmochim. Acta 69, 1883-1898.

Consolmagno G. J. and Drake M. J. (1977) Composition and evolution of the eucrite parent body: evidence from rare earth elements. Geochim. Cosmochim. Acta 41, 1271-1282.

Delaney J. S., Prinz M. Takeda H. (1984) The polymict eucrites. Proc. 15th Lunar Planet. Sci. Conf., J. Geophys. Res., Suppl. 89, C251-C288.

Dohmen, R., Chakraborty, S., Palme, H., Rammensee, W. (1998) Solid-solid reactions mediated by a gas phase: An experimental study of reaction progress and the role of surfaces in the system olivine + iron metal. American Mineralogist 83, 970.984.

Fegley B. jr. (1991) Thermodynamic models of the chemistry of lunar volcanic gases. Geophys. Res. Lett. 18, 2073-2076.

Fogel R. A., Rutherford M. J. (1995) Magmatic volatiles in primitive lunar glasses: I. FTIR and EPMA analyses of Apollo 15 green and yellow glasses and revision of the volatile-assisted fire-fountain theory. Geochim. Cosmochim. Acta 59, 201-215.

Fourcade S., Kienast J.R., Ouzegane K. (1996) Metasomatic effects related to channelled fluid streaming through deep crust : Fenites and associated carbonatites (in Ouzzal proterozoic granulites, Hoggar, Algeria). $J$ Metamorphic Geol. 14, 763-781.

Gounelle M., Chaussidon M., Morbidelli A., Barrat J. A., Engrand C., Zolensky M. E. McKeegan K. D. (2009) A unique basaltic micrometeorite expands the inventory of solar system planetary crusts. PNAS 106, 69046909.

Greenwood J.P., Itoh S., Sakamoto N., Warren P., Taylor L., Yurimoto H. (2011) Hydrogen isotope ratios in lunar rocks indicate delivery of cometary water to the Moon. Nature Geoscience 4, 79-82. 
Greenwood R. C., Franchi I. A., Jambon A., Buchanan P. C. (2005) Widespread magma oceans on asteroidal bodies in the early solar system. Nature $\mathbf{4 3 5}, 916-918$.

Hasegawa S., Murakawa K., Ishiguro M., Nonaka H., Takato N., Davis C., Ueno M., Hiroi T. (2003) Evidence of hydrated and/or hydroxylated minerals on the surface of asteroid 4 Vesta. Geophys. Res. Lett. 30, 21, 2123, doi : 10.1029/2003GL0186727, 2003.

Herd C.D.K., Treiman A.H., McKay G.A., Shearer C.K. (2004) The behavior of Li and B during planetary basalt crystallization. American Miner. 89, 832-840.

Hewins R.G., Newsom H.E. (1988) Igneous activity in the early Solar System. (J.F. Kerridge and M.S. Matthews, eds), Univ. Arizona Press, Tucson AZ, 73-101.

Hua X., Buseck P.R. (1995) Fayalitic in the Kaba and Mokoia carbonaceous chondrites. Geochim. Cosmochim. Acta 59, 563-578.

Hsu W, Crozaz G. (1996) Mineral chemistry and the petrogenesis of eucrites: 1. Noncumulate eucrite. Geochim. Cosmochim. Acta 60, 4571-4591.

Hutcheon I.D., Krot A.N., Keil K., Phinney D.L., Scott E.R.D. (1998) ${ }^{53} \mathrm{Mn}-{ }^{53} \mathrm{Cr}$ dating of fayalite formation in the CV3 chondrite Mokoia: evidence for asteroidal alteration. Science 282, 1865-1867.

Jogo K., Nakamura T., Noguchi T., Zolotov M.Y. (2009) Fayalite in the Vigarano CV3 carbonaceous chondrite: Occurrences, formation age and conditions. Earth Planet. Sci Lett. 287, 320-328.

Krot A.N., Scott E.R.D., Zolensky M.E. (1995) Mineralogical and chemical modification of component in CV3 chondrites: Nebular or asteroidal processing? Meteoritics 30, 748-775.

Krot A.N., Petaev M.I., Scott E.R.D., Choi B.G., Zolensky M.E., Keil K. (1998) Progressive alteration in CV3 chondrites: more evidence for asteroidal alteration. Meteoritics. Planet. Sci. 33, 1065-1085.

Krot A.N., Brearley A.J., Petaev M.I., Kallemeyn G.W., Sears D.W.G., Benoit P.H., Hutcheon I.D., Zolensky M.E., Keil K. (2000) Evidence for low-temperature growth of fayalite and hedenbergite in MacAlpine Hills 88107, an ungrouped carbonaceous chondrite related to the CM-CO clan. Meteoritics Planetary Science 35, $1365-1386$.

McCollom T.M. and Shock E.L. (1998) Fluid-rock interactions in the lower oceanic crust: thermodynamic models of hydrothermal alteration, J. Geophys. Res. 103 (B1) 547-575.

Mayne R.G., McSween H.Y., jr., McCoy T.J., Gale A. (2009) Petrology of the unbrecciated eucrites. Geochim. Cosmochim. Acta 73, 794-819.

McCord T.B., J.B. Adams, T.V. Johnson (1970) Asteroid Vesta: Spectral reflectivity and compositional implications. Science, 168, 1445-1447.

Metzler K., Bobe K., Palme H., Spettel B., Stöffler D. (1995) Thermal and impact metamorphism on the HED parent asteroid. Planet. Space Sci. 43, 499-525.

Mittlefehldt D.W. Lindstrom M.M. (1997) Magnesian basalt clasts from the EET 92014 and Kapoeta howardites and a discussion of alleged primary magnesian HED basalts. Geochim. Cosmochim. Acta 61, 453-462.

Mittlefehldt D.W., McCoy T.J., Goodrich C.A., Kracher A. (1998) Non-chondritic meteorites from asteroidal bodies. in "Planetary Materials" (J.J. Papike, editor), Rev. Miner. 36, chapter 4, 1-195.

Mittlefehldt D.W., Johnson K.N., Herrin J.S. (2011) Fluid-mediated alteration on 4 Vesta - evidence from orthopyroxene clasts in howardites. Lunar Planetary Sci. 42, \# 1834 (abstract).

Miyamoto M., Duke M.B., McKay D.S. (1985) Chemical zoning and homogenization of Pasamonte-type pyroxene and their bearing on thermal metamorphism of a howardite parent body. Proceedings of the $15^{\text {th }}$ Lunar and Planetary Science Conference, J. Geophys. Res. 90, C629-C635. 
Mora C.I., Riciputi L.R., Cole D.R., Walker K.D. (2009) High-temperature hydrothermal alteration of the Boehls Butte anorthosite: origin of a bimodal plagioclase assemblage. Contrib. Mineral. Petrol. 157, 781-795.

Morishita, T., Arai S., Green, D.H. (2003) Evolution of low-Al orthopyroxene in the Horoman peridotite, Japan : an unusual indicator of metasomatizing fluids. J. Petrology 44, 1237-1246.

Newton R.C., Manning C.E. (2000) Quartz solubility in $\mathrm{H}_{2} \mathrm{O}-\mathrm{NaCl}$ and $\mathrm{H}_{2} \mathrm{O}-\mathrm{CO}_{2}$ solutions at deep crust-upper mantle pressures and temperatures: 2-15 kbar and 500-900 ${ }^{\circ}$. Geochim. Cosmochim. Acta 64, 2993-3003.

Peck J.A., Wood J.A. (1987) The origin of ferrous zoning in Allende chondrule olivine. Geochim. Cosmochim. Acta 51, 1503-1510.

Prokof'eva-Mikhailovskaya V.V., Rublevskii A.N., Bochkov V.V. (2008) Water combinations on the surface of the asteroid 4 Vesta. Bulletin of the Crimean Astrophysical Observatory, 104, 162-170.

Pun A., Papike J.J. (1996) Unequilibrated eucrites and the equilibrated Juvinas eucrite : Pyroxene REE systematics and major, minor, and trace element zoning. American Mineralogist 81, 1438-1451.

Python M., Ceuleneer G., Ishida Y., Barrat J.A., Arai S. (2007) Oman diopsidites: a new lithology diagnostic of very high temperature hydrothermal circulation in mantle peridotite below oceanic spreading centres. Earth Planet. Sci. Lett. 255, 289-305.

Rasmussen M.G., Evans B.W., Kuehner S.M. (1998) Low temperature fayalite, greenalite, and minnesotaite from the Overlook gold deposit, Washington: Phase relations in the system $\mathrm{FeO}-\mathrm{SiO}_{2}-\mathrm{H}_{2} \mathrm{O}$. Canadian Mineralogist 36, 147-162.

Roszjar J., Metzler K., Bischoff A., Greenwood R.C., Franchi I.A. (2009) Northwest Africa (NWA) 5073 - an eucritic basalt with cm-sized pyroxenes. Meteoritics and Planet. Sci. , 44 (supplement), A178.

Russell C. T. et al. (2007) Dawn mission to Vesta and Ceres. Earth Moon Planets 101, 65. doi:10.1007/s11038007-9151-9.

Saal A.E., Hauri E.H., Cascio M.L., Van Orman J.A., Rutherford M.C., Cooper R.F. (2008) Volatile content of lunar volcanic glasses and the presence of water in the Moon's interior. Nature 454, 192-196.

Schwartz J.M., McCallum I.S. (2005) Comparative study of equilibrated and unequilibrated eucrites: subsolidus thermal histories of Haraiya and Pasamonte. American Mineralogist 90, 1871-1886.

Scott E.R.D., Greenwood R.C., Franchi I.A., Sanders I.S. (2009) Oxygen isotopic constraints on the origin and parent bodies of eucrites, diogenites, and howardites. Geochim. Cosmochim. Acta 73, 5835-5853.

Takeda H. (1997) Mineralogical records of early planetary processes on the howardite, eucrite, diogenite parent body with reference to Vesta. Meteoritics and Planet. Sci. 32, 841-853.

Takeda H., Graham A.L. (1991) Degree of equilibration of eucritic pyroxenes and thermal metamorphism of the earliest planetary crust. Meteoritics 26, 129-134.

Takeda H., Miyamoto M., Duke M.B., Ishii T. (1978) Crystallization of pyroxenes in lunar KREEP basalt 1586 and meteoritic basalts. Proc. Lunar Planet. Sci. Conf. 9th, 1157-1171.

Takeda H., Wooden J.L., Mori H., Delaney J.S., Prinz M., Nyquist L.E. (1983) Comparison of Yamato and Victoria Land polymict eucrites: A view from mineralogical and isotopic studies. Proc. 14th Lunar Planet. Sci. Conf., J. Geophys. Res. 88, B245-B256.

Takeda H., Mori H., Bogard D.D. (1994) Mineralogy and ${ }^{39} \mathrm{Ar}-{ }^{40} \mathrm{Ar}$ age of an old pristine basalt: thermal history of the HED parent body. Earth Planet. Sci. Lett. 122, 183-194.

Treiman A.H., Lanzirotti A., Xirouchakis D. (2004) Ancient water on asteroid 4-Vesta : evidence from a quartz veinlet in the Serra de Magé eucrite meteorite. Earth Planet. Sci. Lett. 219, 189-199. 
Warren P.H. (2002) Northwest Africa 1000: a new eucrite with maskelynite, unequilibrated pyroxene crisscrossed by fayalitic-rich veins, and Stannern-like geochemistry. Lunar Planet. Sci. 33, \#1147 (abstract).

Warren P.H., Gessler P. (2001) Bluewing 001: a new eucrite with extremely unequilibrated pyroxene, cognate (?) eucritic xenoliths, and Stannern like geochemistry. Lunar Planet. Sci. 32, \#1970 (abstact).

Wasson J.T., Krot A.N. (1994) Fayalite-silica association in unequilibrated ordinary chondrites: Evidence for aqueous alteration on a parent body. Earth Planet. Sci. Lett. 122, 403-416.

Wiechert U. H., Halliday A. N., Palme H. and Rumble D. (2004) Oxygen isotope evidence for rapid mixing of the HED meteorite parent body. Earth Planet. Sci. Lett. 221, 373-382.

Yakovlev O. I., Parfenova O. V. (1980) The role of vaporization and condensation in the formation of the chemical composition of impactites. Proceedings, $\mathbf{1 1}^{\text {th }}$ Lunar and Planetary Science Conference. pp. 12851287.

Yamaguchi A., Mikouchi T. (2005) Heating experiments of the HaH 262 eucrite and implication for the metamorphic history of highly metamorphosed eucrites. Lunar and Planetary Science 36, CD\#1574.

Yamaguchi A., Takeda H. (1992) Mineralogical study of some brecciated Antarctic eucrite. Proc. NIPR Symp. Antarctic Meteorites, 5, 242-257.

Yamaguchi A., Taylor G.J., and Keil K. (1996) Global crustal metamorphism of the eucrite parent body. Icarus 124, 97-112.

Yamaguchi A., Taylor G.J., Keil K., Floss C., Crozaz G., Nyquist L.E., Bogard D.D., Garrison D.H., Reese Y.D., Wiesmann H., Shih C.Y. (2001) Post-crystallization reheating and partial melting of eucrite EET90020 by impact into the hot crust of asteroid 4-Vesta 4.5 Ga ago. Geochim. Cosmochim. Acta 20, 3577-3599.

Yamaguchi A., Clayton R. N., Mayeda T. K., Ebihara M., Oura Y., Miura Y. N., Haramura H., Misawa K., Kojima H., Nagao K. (2002) A new source of basaltic meteorites inferred from Northwest Africa 011. Science 296, 334-336.

Yamaguchi A., Barrat J.A., Greenwood R.C., Shirai N., Okamoto C., Setoyanagi, Ebihara M., Franchi I.A., Bohn M. (2009) Crustal partial melting on Vesta : evidence from highly metamorphosed eucrites. Geochim. Cosmochim. Acta 73, 7262-7182.

Zolensky M.E., Krot A.N., Benedix G. (2008) Record of low temperature alteration in asteroids. Reviews Miner. Geochemistry 68, 429-462.

Zolotov, M.Yu., Mironenko, M.V., Shock, E.L., 2006. Thermodynamic constraints on fayalite formation on parent bodies of chondrites. Meteorit. Planet. Sci. 41, 1775-1796. 
Table 1. Main petrographical features of the studied samples

\begin{tabular}{|c|c|c|c|c|c|}
\hline \multirow[t]{2}{*}{ type } & \multirow{2}{*}{$\begin{array}{c}\text { sample studied } \\
\text { texture }\end{array}$} & \multicolumn{3}{|c|}{ Primary phases } & \multirow{2}{*}{$\begin{array}{c}\text { Secondary } \\
\text { phases }\end{array}$} \\
\hline & & Plagioclase & Pyroxene & accessory phases & \\
\hline \multicolumn{6}{|c|}{ Pasamonte (HIGP, PTS UNM 239) } \\
\hline $\begin{array}{l}\text { Polymict eucrite, } \\
\text { ungrouped }\end{array}$ & subophitic clast & $A n_{91-77}$ & $\begin{array}{l}\mathrm{Mg}_{66-36} \mathrm{Ca}_{5-11} \mathrm{Fe}_{29-53} \\
\text { augite close to mes. }\end{array}$ & chr, mes, sil, tr & $\begin{array}{l}\text { Fe-rich px, tr } \\
\text { Ol }\left(F_{64-70}\right)\end{array}$ \\
\hline \multicolumn{6}{|c|}{ NWA 049 (Bruno and Carine Fectay, thick section UBO) } \\
\hline Polymict eucrite & subophitic clasts & $A n_{94-81}$ & $\begin{array}{l}\text { cores } \mathrm{Mg}_{65} \mathrm{Ca}_{5} \mathrm{Fe}_{30} \\
\text { rims with augite exsol. }\end{array}$ & $\begin{array}{l}\text { chr, ilm, tr, mes, } \\
\text { met, zr. }\end{array}$ & $\begin{array}{c}\text { Fe-rich px, tr } \\
\text { OI }\left(\mathrm{Fa}_{76-80}\right), \mathrm{PI}\left(\mathrm{An}_{97-98}\right)\end{array}$ \\
\hline \multicolumn{6}{|c|}{ NWA 2061 (NAU, thick section UBO) } \\
\hline $\begin{array}{l}\text { Unbrecciatted } \\
\text { eucrite }\end{array}$ & porphyritic texture & $A n_{86-77}$ & $\begin{array}{c}\mathrm{Mg}_{65} \mathrm{Ca}_{5} \mathrm{Fe}_{30} \text { to } \\
\mathrm{Mg}_{19} \mathrm{Ca}_{27} \mathrm{Fe}_{54}\end{array}$ & $\begin{array}{l}\text { chr, ilm, tr, mes, } \\
\text { met, sil., phos., zr }\end{array}$ & $\begin{array}{c}\text { Fe-rich px, tr } \\
\text { OI }\left(\mathrm{Fa}_{78-81}\right), \mathrm{PI}\left(\mathrm{An}_{98-99}\right)\end{array}$ \\
\hline \multicolumn{6}{|c|}{ Y-75011 (NIPR, PTS ,97 and ,112) } \\
\hline Polymict eucrite & subophitic clasts & $A n_{90-71}$ & $\begin{array}{c}\mathrm{Mg}_{69} \mathrm{Ca}_{3.5} \mathrm{Fe}_{27.5} \text { to } \\
\mathrm{Mg}_{15} \mathrm{Ca}_{25} \mathrm{Fe}_{60}\end{array}$ & $\begin{array}{l}\text { ilm, sulf, mes, } \\
\text { phos., zr. }\end{array}$ & $\begin{array}{c}\text { Fe-rich px, tr } \\
\text { OI }\left(\mathrm{Fa}_{70-77}\right), \mathrm{PI}\left(\mathrm{An}_{97-98}\right)\end{array}$ \\
\hline \multicolumn{6}{|c|}{ Y-82202 (NIPR, PTS ,51) } \\
\hline Monomict eucrite & $\begin{array}{l}\text { subophitic clasts } \\
\text { contains glass veins }\end{array}$ & $A n_{91-77}$ & $\begin{array}{c}\mathrm{Mg}_{67} \mathrm{Ca}_{4} \mathrm{Fe}_{29} \text { to } \\
\mathrm{Mg}_{21} \mathrm{Ca}_{30} \mathrm{Fe}_{49}\end{array}$ & ilm, chr, sil, tr & $\begin{array}{l}\text { Fe-rich px, tr } \\
\text { Ol }\left(\mathrm{Fa}_{80-86}\right), \mathrm{PI} ?\end{array}$ \\
\hline \multicolumn{6}{|c|}{ Sioux Co. (UNM, PTS UNM 621) } \\
\hline Polymict eucrite & $\begin{array}{l}\text { equilibrated pyroxene clasts } \\
\text { containing olivine veinlets }\end{array}$ & $A n_{94-71}$ & $\begin{array}{l}\text { Pyroxenes with } \\
\text { Augite exsolutions }\end{array}$ & & $\begin{array}{c}\text { Ol }\left(\mathrm{Fa}_{74-76}\right) \\
\mathrm{PI}\left(\mathrm{An}_{89.8-97.2}\right)\end{array}$ \\
\hline
\end{tabular}

Data from Hsu and Crozaz (1996), Yamaguchi and Takeda (1992), Buchanan et al. (1996) and this study (chr : chromite, ilm : ilmenite, mes : mesostasis, met : metal, phos : phosphate, sil : silica, tr : troilite, zr : zircon). 
Table 2a. Average and representative pyroxene compositions (in wt\%) from Pasamonte, NWA 049, NWA 2061, Y-75011, Y-82202 and Sioux co (n.a.: not analyzed).

\section{Pasamonte}

\section{pyroxene core}

rim in contact with plagioclase

rim in contact with mesostasis

High-Fe secondary pyroxene

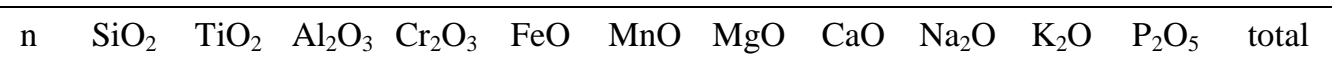

$\begin{array}{lll}20 & 53.5 & 0.09\end{array}$

$\begin{array}{ll}1.37 & 0.73\end{array}$

$\begin{array}{llllll}5 & 51.3 & 0.09 & 0.26 & 0.07\end{array}$

$\begin{array}{lll}3 & 50.7 & 0.12\end{array}$

\section{NWA 049}

Pristine cores

High-Fe secondary pyroxenes

High-Fe low Al secondary px

$\begin{array}{llllllllllllll}78 & 52.7 & 0.12 & 1.35 & 0.71 & 20.9 & 0.71 & 21.5 & 2.61 & <0.03 & 0.01 & \text { n.a. } & 100.6 & \mathrm{Mg}_{61.2} \mathrm{Ca}_{5.3} \mathrm{Fe}_{33.4} \\ 20 & 49.9 & 0.12 & 1.19 & 0.49 & 31.6 & 0.95 & 13.9 & 2.32 & <0.03 & 0.01 & \text { n.a. } & 100.5 & \mathrm{Mg}_{41.7} \mathrm{Ca}_{5.0} \mathrm{Fe}_{53.3} \\ 20 & 50.4 & 0.11 & 0.18 & 0.17 & 34.3 & 1.08 & 12.9 & 1.52 & <0.03 & <0.01 & \text { n.a. } & 100.7 & \mathrm{Mg}_{38.9} \mathrm{Ca}_{3.3} \mathrm{Fe}_{57.8}\end{array}$

\section{NWA 2061}

pyroxene core

rims

High-Fe secondary pyroxenes

$\begin{array}{cccccccccccccc}23 & 53.4 & 0.17 & 1.51 & 0.95 & 19.0 & 0.65 & 23.2 & 2.48 & <0.03 & 0.01 & \text { n.a. } & 101.4 & \mathrm{Mg}_{65.1} \mathrm{Ca}_{5.0} \mathrm{Fe}_{29.9} \\ 6 & 48.1 & 0.88 & 1.17 & 0.24 & 32.3 & 1.09 & 6.13 & 11.3 & 0.03 & <0.01 & \text { n.a. } & 101.2 & \mathrm{Mg}_{18.9} \mathrm{Ca}_{25.0} \mathrm{Fe}_{56.0} \\ 3 & 49.6 & 0.20 & 1.26 & 0.50 & 33.4 & 1.06 & 13.3 & 1.59 & <0.03 & 0.02 & 0.01 & 100.9 & \mathrm{Mg}_{40.0} \mathrm{Ca}_{3.4} \mathrm{Fe}_{56.5}\end{array}$

\section{Y-75011}

pyroxene core

rim

High-Fe secondary pyroxene

\section{Y-82202}

\begin{tabular}{lcccccccccccccc} 
pyroxene core & 14 & 51.1 & 0.26 & 2.75 & 1.06 & 20.4 & 0.75 & 20.3 & 3.57 & 0.03 & $<0.01$ & n.a. & 100.2 & $\mathrm{Mg}_{59.2} \mathrm{Ca}_{7.5} \mathrm{Fe}_{33.3}$ \\
Fe-rich rim & 3 & 47.2 & 1.25 & 1.65 & 0.12 & 30.6 & 0.93 & 4.35 & 14.7 & $<0.03$ & $<0.01$ & n.a. & 100.7 & $\mathrm{Mg}_{13.6} \mathrm{Ca}_{32.9} \mathrm{Fe}_{53.6}$ \\
Ca-rich rim & 5 & 48.9 & 1.51 & 1.69 & 0.26 & 22.0 & 0.61 & 5.89 & 20.6 & 0.04 & $<0.01$ & n.a. & 101.4 & $\mathrm{Mg}_{17.8} \mathrm{Ca}_{44.8} \mathrm{Fe}_{37.4}$ \\
High-Fe secondary pyroxene & 1 & 49.6 & 0.09 & 1.27 & 0.59 & 33.5 & 1.02 & 13.1 & 2.11 & 0.05 & $<0.01$ & n.a. & 101.3 & $\mathrm{Mg}_{39.3} \mathrm{Ca}_{4.5} \mathrm{Fe}_{56.2}$ \\
\hline
\end{tabular}


Table 2a (cont.)

\begin{tabular}{|c|c|c|c|c|c|c|c|c|c|c|c|c|c|c|}
\hline & $\mathrm{n}$ & $\mathrm{SiO}_{2}$ & $\mathrm{TiO}_{2}$ & $\mathrm{Al}_{2} \mathrm{O}_{3}$ & $\mathrm{Cr}_{2} \mathrm{O}_{3}$ & $\mathrm{FeO}$ & $\mathrm{MnO}$ & $\mathrm{MgO}$ & $\mathrm{CaO}$ & $\mathrm{Na}_{2} \mathrm{O}$ & $\mathrm{K}_{2} \mathrm{O}$ & $\mathrm{P}_{2} \mathrm{O}_{5}$ & total & Endmembers \\
\hline px 1, low Ca host & 3 & 404 & 000 & 008 & 002 & 348 & 106 & 127 & 068 & $<002$ & $<001$ & $n=0$ & 008 & $\mathrm{Mo}$ \\
\hline px 1 , augite & 3 & 51.6 & 0.21 & 0.46 & 0.19 & 14.5 & 0.54 & 11.5 & 21.1 & 0.04 & 0.01 & n.a. & 100.0 & $\mathrm{Mg}_{33.0} \mathrm{Ca}_{43.6} \mathrm{Fe}_{23.4}$ \\
\hline px 2, low Ca host & 1 & 49.8 & 0.18 & 0.28 & 0.13 & 35.8 & 1.13 & 9.92 & 4.24 & 0.06 & $<0.01$ & n.a. & 101.6 & $\mathrm{Mg}_{30.0} \mathrm{Ca}{ }_{9.2} \mathrm{Fe}_{60.8}$ \\
\hline px 2, augite & 13 & 50.9 & 0.22 & 0.52 & 0.20 & 17.7 & 0.56 & 9.21 & 20.5 & 0.05 & 0.01 & n.a. & 99.8 & $\mathrm{Mg}_{27.2} \mathrm{Ca}{ }_{43.5} \mathrm{Fe}_{29.2}$ \\
\hline low Ca px vein in px 2 & 22 & 49.8 & 0.07 & 0.11 & 0.06 & 37.4 & 1.28 & 10.3 & 1.61 & $<0.03$ & 0.01 & n.a. & 100.6 & $\mathrm{Mg}_{31.8} \mathrm{Ca}_{3.6} \mathrm{Fe}_{64.6}$ \\
\hline
\end{tabular}


Table 2b. Average compositions of olivine in veins (in wt\%) from Pasamonte, NWA 049, NWA 2061, Y-75011, Y-82202 and Sioux Co.

\begin{tabular}{lccccccccccccccccc}
\hline & $\mathrm{n}$ & $\mathrm{SiO}_{2}$ & $\mathrm{TiO}_{2}$ & $\mathrm{Al}_{2} \mathrm{O}_{3}$ & $\mathrm{Cr}_{2} \mathrm{O}_{3}$ & $\mathrm{FeO}$ & $\mathrm{MnO}$ & $\mathrm{MgO}$ & $\mathrm{CaO}$ & $\mathrm{Na}_{2} \mathrm{O}$ & $\mathrm{K}_{2} \mathrm{O}$ & $\mathrm{P}_{2} \mathrm{O}_{5}$ & total & \multicolumn{2}{c}{$\mathrm{Fo}(\mathrm{mol} \%) \mathrm{Fa}(\mathrm{mol} \%) \mathrm{Tp}(\mathrm{mol} \%)$} \\
Pasamonte & 9 & 32.9 & 0.03 & 0.03 & 0.11 & 51.5 & 1.05 & 14.4 & 0.06 & $<0.03$ & $<0.01$ & 0.04 & 100.1 & 32.8 & 65.8 & 1.4 \\
NWA 049 & 49 & 31.5 & $<0.03$ & 0.06 & 0.11 & 59.1 & 1.38 & 8.32 & 0.13 & $<0.03$ & $<0.01$ & n.a. & 100.6 & 19.7 & 78.4 & 1.9 \\
NWA 2061 & 11 & 31.3 & $<0.03$ & 0.08 & 0.21 & 59.5 & 1.41 & 7.75 & 0.14 & $<0.03$ & $<0.01$ & 0.03 & 100.4 & 18.5 & 79.6 & 1.9 \\
Y-75011 & 52 & 32.6 & $<0.03$ & 0.03 & 0.07 & 55.5 & 1.21 & 11.4 & 0.10 & n.a. & n.a. & n.a. & 100.9 & 26.4 & 72.0 & 1.6 \\
Y-82202 & 4 & 30.7 & 0.06 & 0.10 & 0.08 & 60.3 & 1.48 & 6.23 & 0.21 & 0.03 & 0.02 & n.a. & 99.3 & 15.2 & 82.7 & 2.1 \\
Sioux Co & 11 & 32.4 & $<0.03$ & $<0.03$ & 0.04 & 57.8 & 1.32 & 9.53 & 0.15 & $<0.03$ & $<0.01$ & n.a. & 101.3 & 22.3 & 75.9 & 1.8 \\
\hline
\end{tabular}


Table 2c. Average and representative plagioclase compositions (in wt\%) from NWA 049, NWA 2061, Y-75011, and Sioux co.

\begin{tabular}{|c|c|c|c|c|c|c|c|c|c|c|c|c|c|c|c|c|}
\hline & $\mathrm{n}$ & $\mathrm{SiO}_{2}$ & $\mathrm{TiO}_{2}$ & $\mathrm{Al}_{2} \mathrm{O}_{3}$ & $\mathrm{Cr}_{2} \mathrm{O}_{3}$ & $\mathrm{FeO}$ & $\mathrm{MnO}$ & $\mathrm{MgO}$ & $\mathrm{CaO}$ & $\mathrm{Na}_{2} \mathrm{O}$ & $\mathrm{K}_{2} \mathrm{O}$ & $\mathrm{P}_{2} \mathrm{O}_{5}$ & total & $\mathrm{An}(\mathrm{mol} \%)$ & $\mathrm{Ab}(\mathrm{mol} \%)$ & Or $(\mathrm{mol} \%)$ \\
\hline NWA 049 & & & & & & & & & & & & & & & & \\
\hline average primary pl. & 64 & 45.3 & $<0.03$ & 34.8 & $<0.03$ & 0.37 & 0.01 & 0.03 & 18.8 & 0.99 & 0.05 & 0.01 & 100.4 & 91.1 & 8.7 & 0.3 \\
\hline core & 5 & 44.4 & $<0.03$ & 34.9 & $<0.03$ & 0.50 & 0.01 & 0.03 & 19.2 & 0.71 & 0.04 & 0.01 & 99.8 & 93.5 & 6.2 & 0.2 \\
\hline rim & 2 & 48.0 & 0.03 & 33.5 & 0.14 & 0.44 & $<0.01$ & $<0.01$ & 16.8 & 1.97 & 0.14 & 0.01 & 101.0 & 81.8 & 17.4 & 0.8 \\
\hline secondary pl. & 20 & 43.3 & $<0.03$ & 35.9 & 0.06 & 1.08 & 0.02 & 0.04 & 19.9 & 0.25 & 0.02 & 0.02 & 100.6 & 97.7 & 2.2 & 0.1 \\
\hline \multicolumn{17}{|l|}{ NWA 2061} \\
\hline average primary pl. & 67 & 49.5 & 0.03 & 31.7 & $<0.03$ & 0.97 & 0.02 & 0.11 & 16.5 & 1.86 & 0.17 & 0.01 & 100.9 & 82.2 & 16.8 & 1.0 \\
\hline core & 5 & 48.4 & $<0.03$ & 32.9 & $<0.03$ & 0.79 & 0.03 & 0.07 & 17.4 & 1.57 & 0.11 & 0.01 & 101.3 & 85.4 & 14.0 & 0.6 \\
\hline rim & 3 & 50.9 & 0.03 & 31.6 & $<0.03$ & 0.58 & $<0.01$ & 0.05 & 15.6 & 2.32 & 0.24 & 0.02 & 101.3 & 77.7 & 20.9 & 1.4 \\
\hline secondary pl. & 4 & 42.2 & 0.04 & 35.6 & n.a. & 1.30 & 0.01 & 0.03 & 19.4 & 0.14 & 0.01 & n.a. & 98.8 & 98.6 & 1.3 & 0.1 \\
\hline \multicolumn{17}{|l|}{ Y-75011 } \\
\hline average primary pl. & 113 & 48.4 & 0.03 & 32.3 & $<0.03$ & 0.73 & 0.02 & 0.10 & 16.8 & 1.62 & 0.16 & n.a. & 100.1 & 84.3 & 14.7 & 1.0 \\
\hline core & 10 & 46.7 & 0.02 & 33.5 & $<0.03$ & 0.58 & 0.03 & 0.08 & 17.7 & 1.14 & 0.08 & n.a. & 99.9 & 89.2 & 10.3 & 0.5 \\
\hline rim & 10 & 49.7 & 0.04 & 31.3 & $<0.03$ & 0.77 & 0.04 & 0.09 & 15.7 & 2.02 & 0.25 & n.a. & 100.0 & 79.9 & 18.6 & 1.5 \\
\hline secondary pl. & 10 & 43.8 & 0.01 & 35.8 & $<0.03$ & 1.08 & 0.05 & 0.03 & 19.5 & 0.24 & 0.02 & n.a. & 100.6 & 97.7 & 2.1 & 0.1 \\
\hline \multicolumn{17}{|l|}{ Sioux Co } \\
\hline high Ca primary pl. & 3 & 44.7 & $<0.01$ & 34.8 & $<0.03$ & 0.25 & 0.02 & 0.01 & 18.8 & 0.69 & 0.04 & n.a. & 99.4 & 93.6 & 6.2 & 0.2 \\
\hline Low Ca primary pl. & 1 & 50.3 & 0.02 & 31.1 & $<0.03$ & 0.23 & $<0.01$ & $<0.01$ & 14.5 & 2.68 & 0.67 & n.a. & 99.5 & 71.9 & 24.1 & 3.9 \\
\hline An-rich inclusions & 9 & 43.6 & 0.01 & 35.2 & 0.01 & 0.71 & 0.02 & 0.01 & 19.4 & 0.36 & 0.01 & n.a. & 99.3 & 96.7 & 3.2 & 0.1 \\
\hline An-poor inclusions & 3 & 45.5 & 0.01 & 34.2 & 0.02 & 0.80 & 0.02 & $<0.01$ & 18.2 & 1.04 & 0.05 & n.a. & 99.8 & 90.4 & 9.3 & 0.3 \\
\hline
\end{tabular}


Table 3. Trace element abundances in representative pyroxenes from NWA 049 (in $\mu \mathrm{g} / \mathrm{g}$ ).

\begin{tabular}{lcc}
\hline & Pristine Px & Fe-rich Px \\
$\mathrm{Ti}$ & 859 & 751 \\
$\mathrm{Y}$ & 2.36 & 3.54 \\
$\mathrm{Nb}$ & 0.05 & 0.14 \\
$\mathrm{La}$ & 0.020 & 0.066 \\
$\mathrm{Ce}$ & 0.066 & 0.189 \\
$\mathrm{Pr}$ & 0.015 & 0.033 \\
$\mathrm{Nd}$ & 0.10 & 0.19 \\
$\mathrm{Sm}$ & 0.062 & 0.096 \\
$\mathrm{Eu}$ & 0.009 & 0.009 \\
$\mathrm{Gd}$ & 0.14 & 0.20 \\
$\mathrm{Dy}$ & 0.30 & 0.41 \\
$\mathrm{Er}$ & 0.31 & 0.48 \\
$\mathrm{Yb}$ & 0.44 & 0.82 \\
$\mathrm{Lu}$ & 0.066 & 0.13 \\
$\mathrm{Hf}$ & 0.06 & 0.08 \\
$\mathrm{Ta}$ & 0.003 & 0.006 \\
\hline
\end{tabular}




\section{Figure captions}

1.Backscattered electron images of Pasamonte (Cr: chromite, Ol: olivine, Pl: plagioclase, $\mathrm{Px}$ : pyroxene, Tr: troilite).

2. Pyroxene and olivine compositions from Pasamonte (a: quadrilateral pyroxene and olivine compositions, b: $\mathrm{Ti} / \mathrm{Al}$ vs. $\mathrm{Mg} /(\mathrm{Fe}+\mathrm{Mg})$ plot, c: $\mathrm{Fe} / \mathrm{Mn}$ vs. $\mathrm{Mg} /(\mathrm{Fe}+\mathrm{Mg}))$.

3. Fe/Mg profiles measured across olivine veinlets and their hosts from Pasamonte, NWA 2061, Y-75011 and Y-82202.

4. Backscattered electron images of Y-75011 (Ol: olivine, Mes: mesostasis, P11: primary plagioclase, PL2: secondary plagioclase, Px: pyroxene, Tr: troilite).

5. Quadrilateral pyroxene and olivine compositions from NWA 049, NWA 2061, Y-75011 and Y-82202.

6. Chemical zoning (core-rim) of a large pyroxene from NWA 2061. This profile is devoid of cracks displaying a Fe-enrichment.

7. $\mathrm{Ti} / \mathrm{Al}$ and $\mathrm{Fe} / \mathrm{Mn}$ vs. $\mathrm{Mg} /(\mathrm{Mg}+\mathrm{Fe})$ plots for pyroxenes and olivines from NWA 2061 and NWA 049.

8. Compositions of plagioclases from NWA 049, NWA 2061 and Y-75011.

9. Backscattered electron images of NWA 049 (Cc: calcite (terrestrial weathering), Ol: olivine, P11: primary plagioclase, PL2: secondary plagioclase, Mg-Px: pristine pyroxene area, Fe-Px: Fe-rich secondary pyroxene (chiefly Al-poor type), Tr: troilite).

10. Chemical zoning of a pyroxene from NWA 049, displaying cracks with Fe-enrichment, and olivine veinlets.

11. REE patterns of pyroxenes from NWA 049. Pyroxenes from unequilibrated eucrites are taken from Pun and Papike (1996).

12. Sioux County. a: Backscattered electron image an equilibrated pyroxene displaying an olivine veinlet. b: Quadrilateral pyroxene and olivine compositions from two clasts. c: Compositions of plagioclase.

Supplementary figures:

1. Backscattered electron image of Pasamonte and maps of Fe of two selected areas displaying Fe-enrichment along the fractures in pyroxenes. Olivine appears red in the maps.

2. Backscattered electron image of NWA 049 and maps of Fe and Na. Notice the secondary plagioclase veinlets (blue) in the map of $\mathrm{Na}$. 

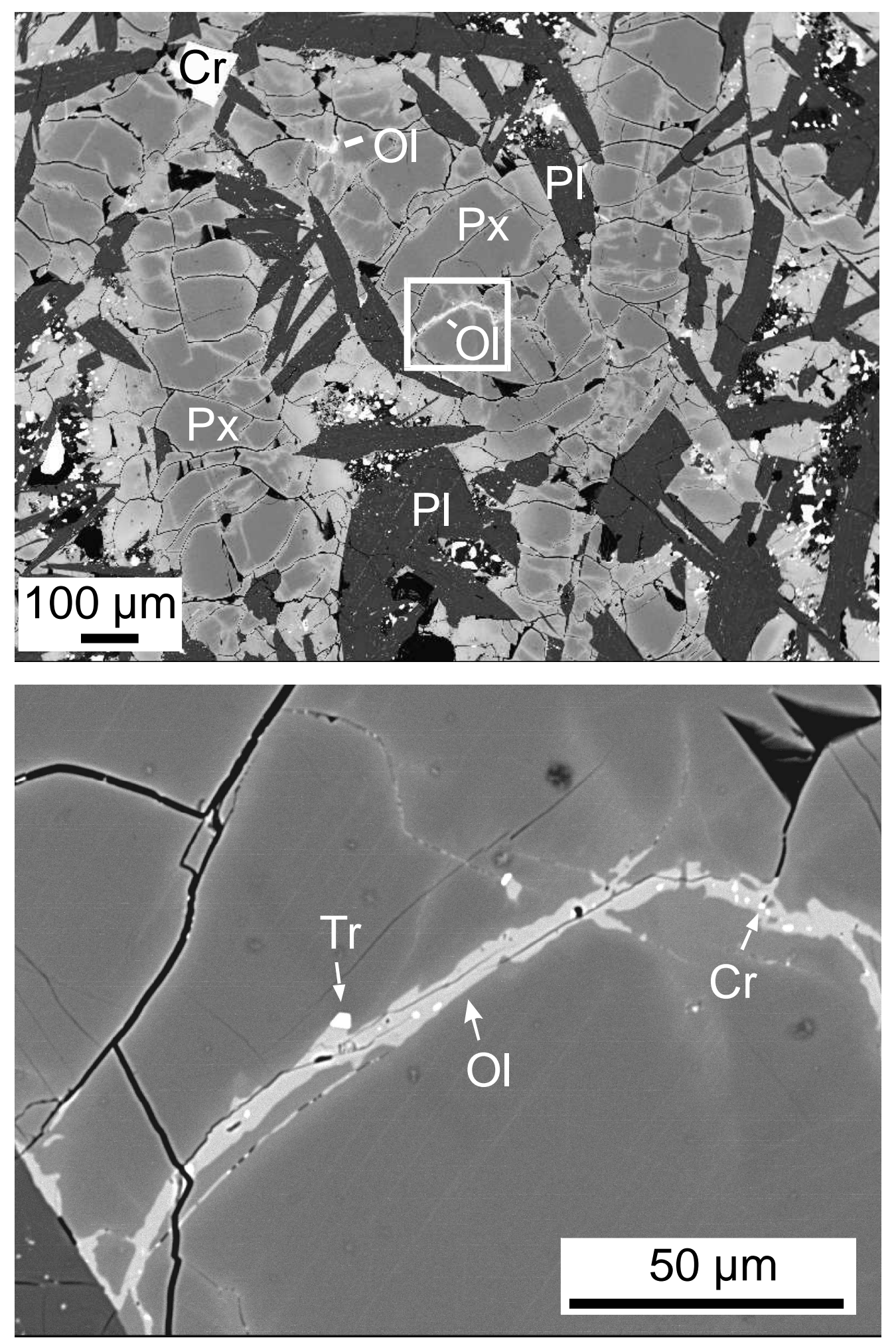

1.Backscattered electron images of Pasamonte (Cr: chromite, Ol: olivine, Pl: plagioclase, Px: pyroxene, Tr: troilite). 

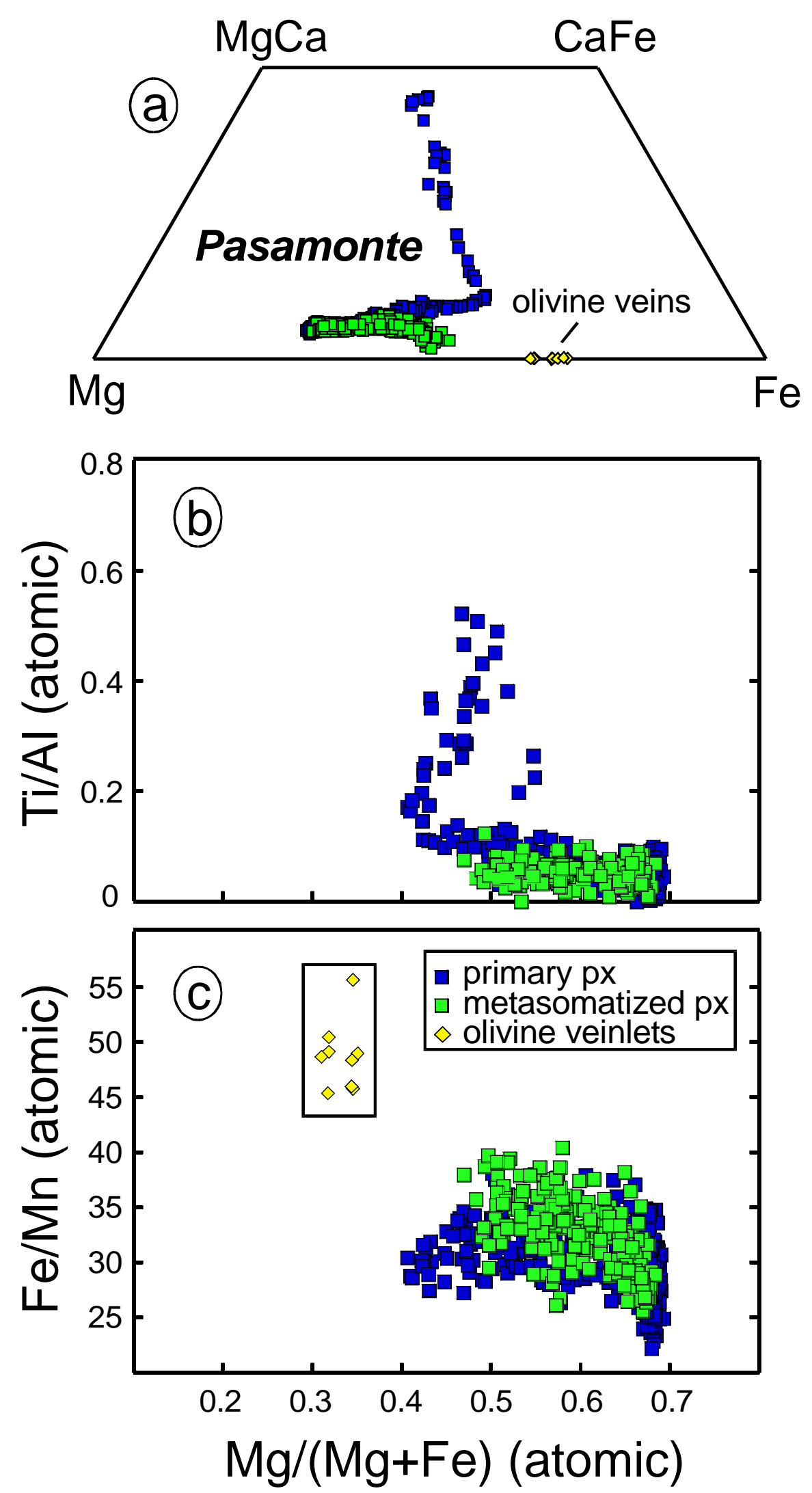

2. Pyroxene and olivine compositions from Pasamonte (a: quadrilateral pyroxene and olivine compositions, b: $\mathrm{Ti} / \mathrm{Al}$ vs. $\mathrm{Mg} /(\mathrm{Fe}+\mathrm{Mg})$ plot, c: Fe/Mn vs. $\mathrm{Mg} /(\mathrm{Fe}+\mathrm{Mg})$ ). 


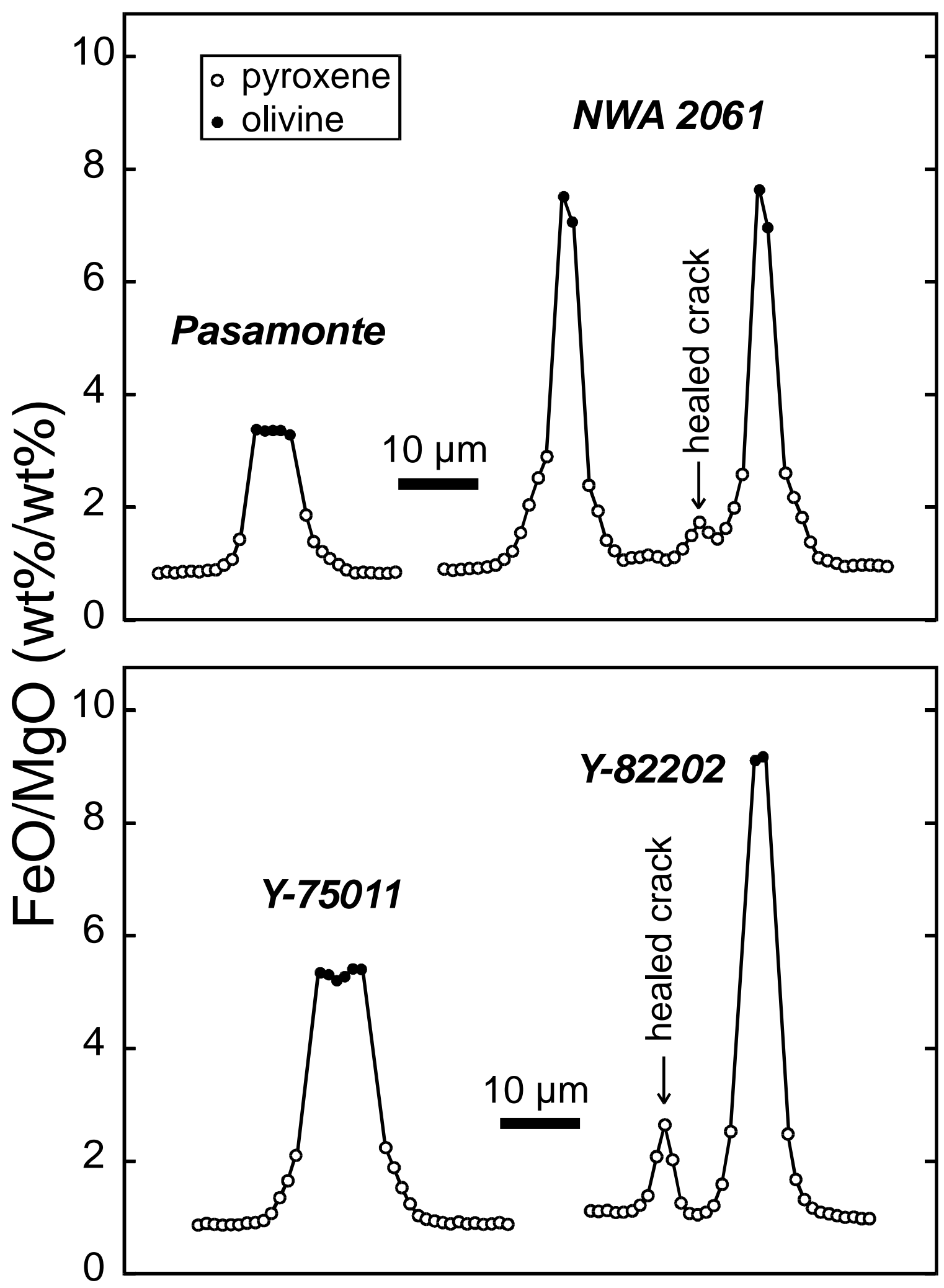

3. Fe/Mg profiles measured across olivine veinlets and their hosts from Pasamonte, NWA 2061, Y-75011 and Y-82202. 

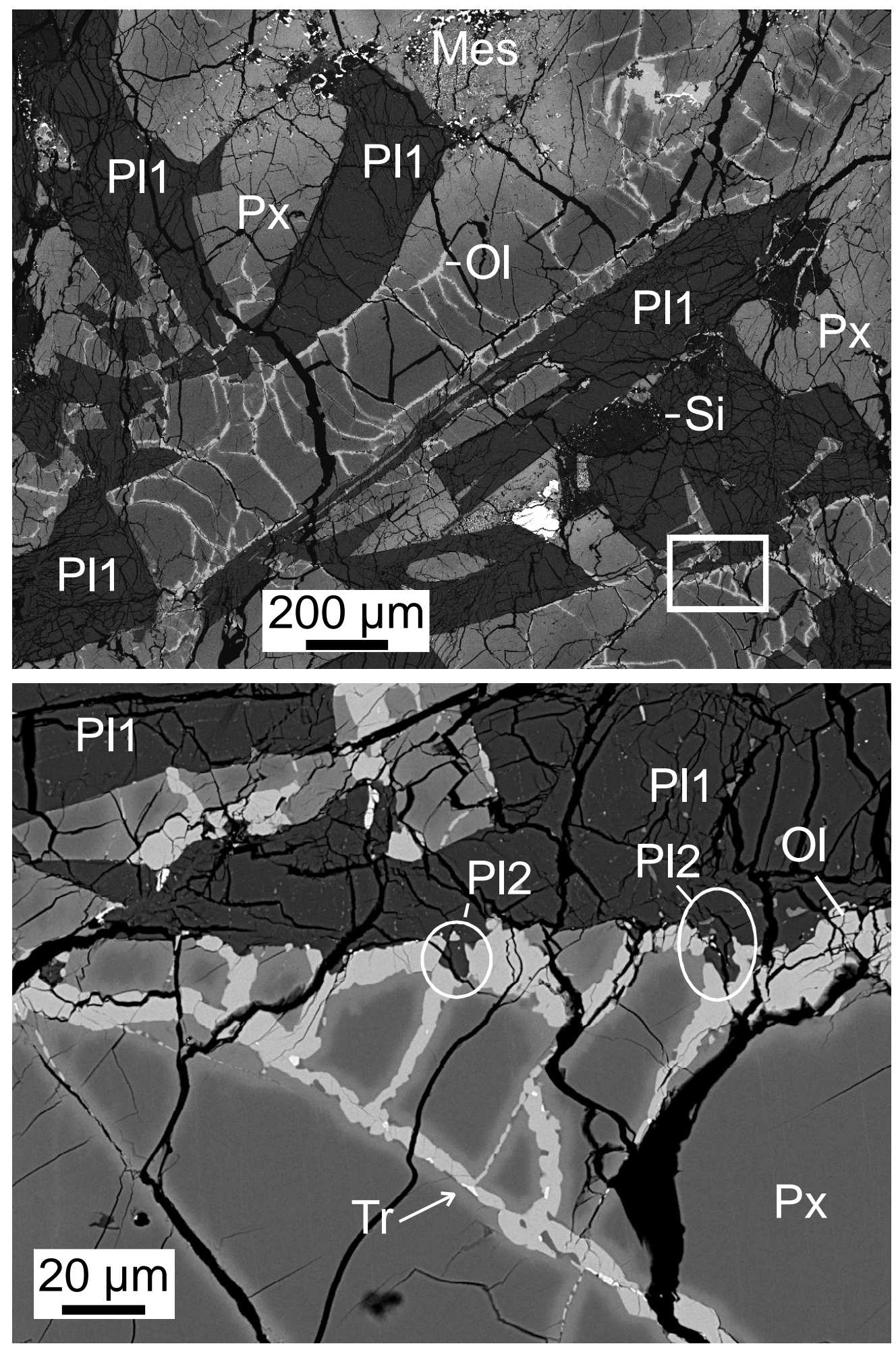

4. Backscattered electron images of Y-75011 (Ol: olivine, Mes: mesostasis, P11: primary plagioclase, PL2: secondary plagioclase, Px: pyroxene, Tr: troilite). 


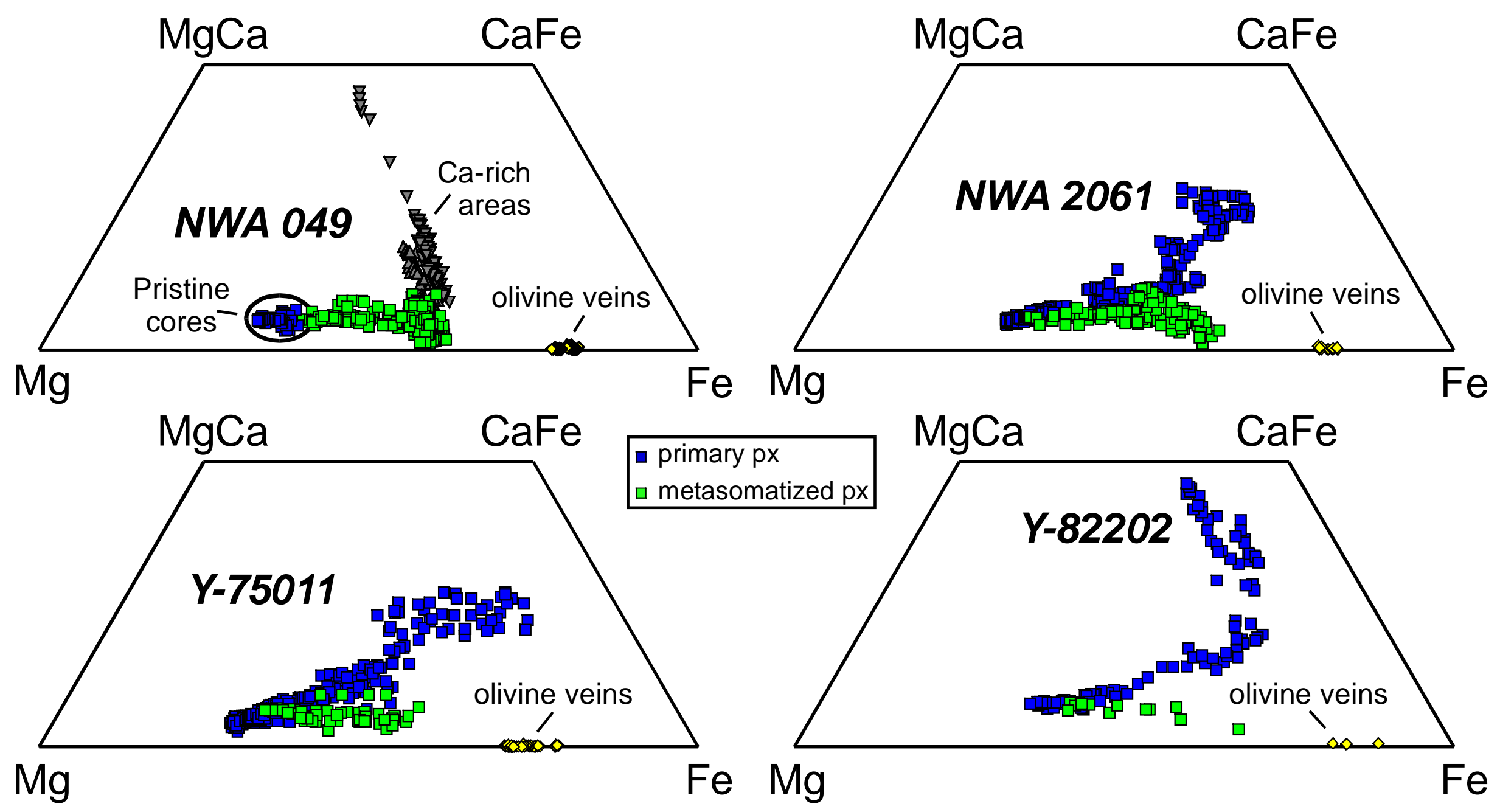

5. Quadrilateral pyroxene and olivine compositions from NWA 049, NWA 2061, Y-75011 and Y-82202. 

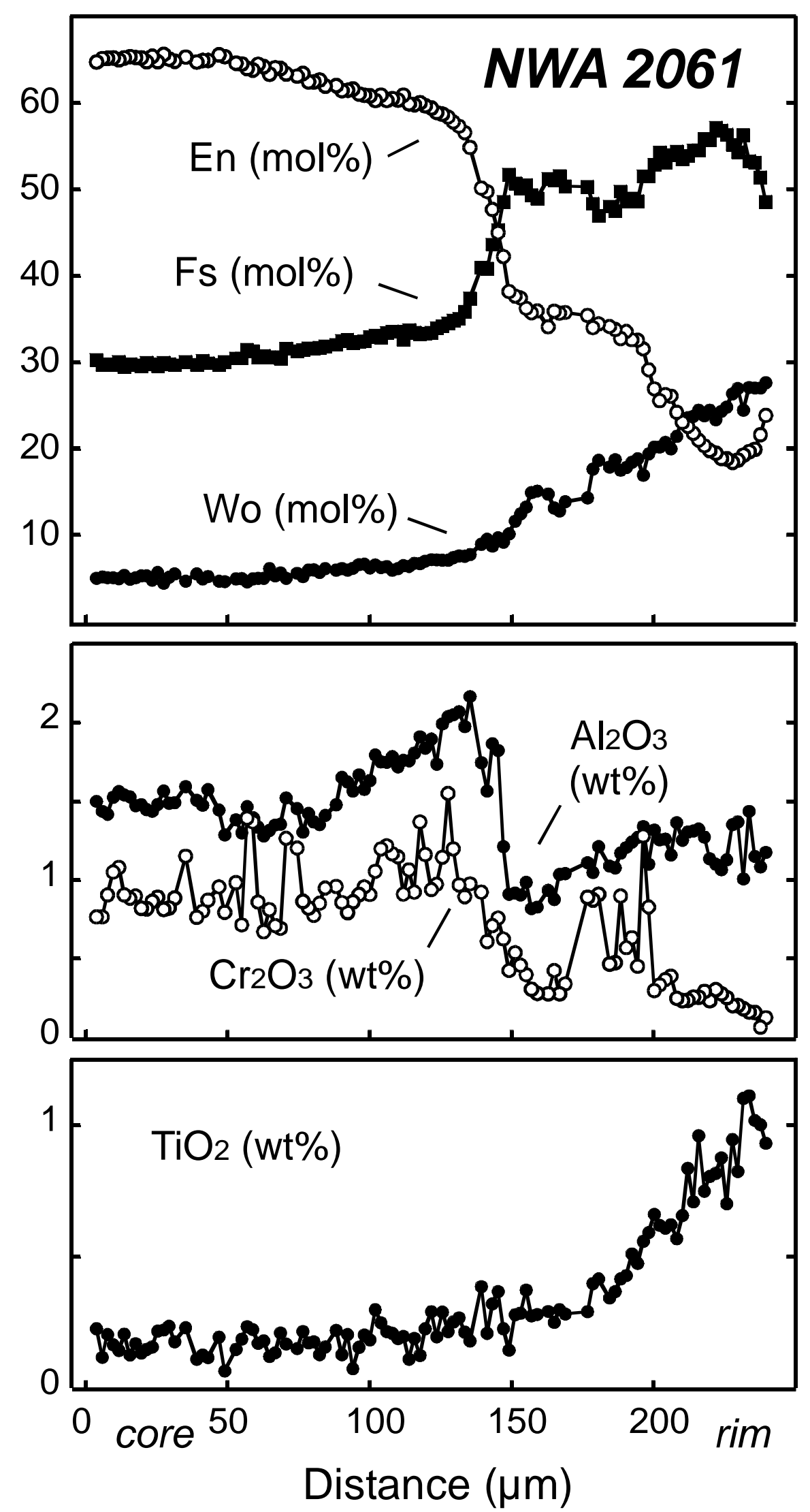

6. Chemical zoning (core-rim) of a large pyroxene from NWA 2061. This profile is devoid of cracks displaying a Fe-enrichment. 

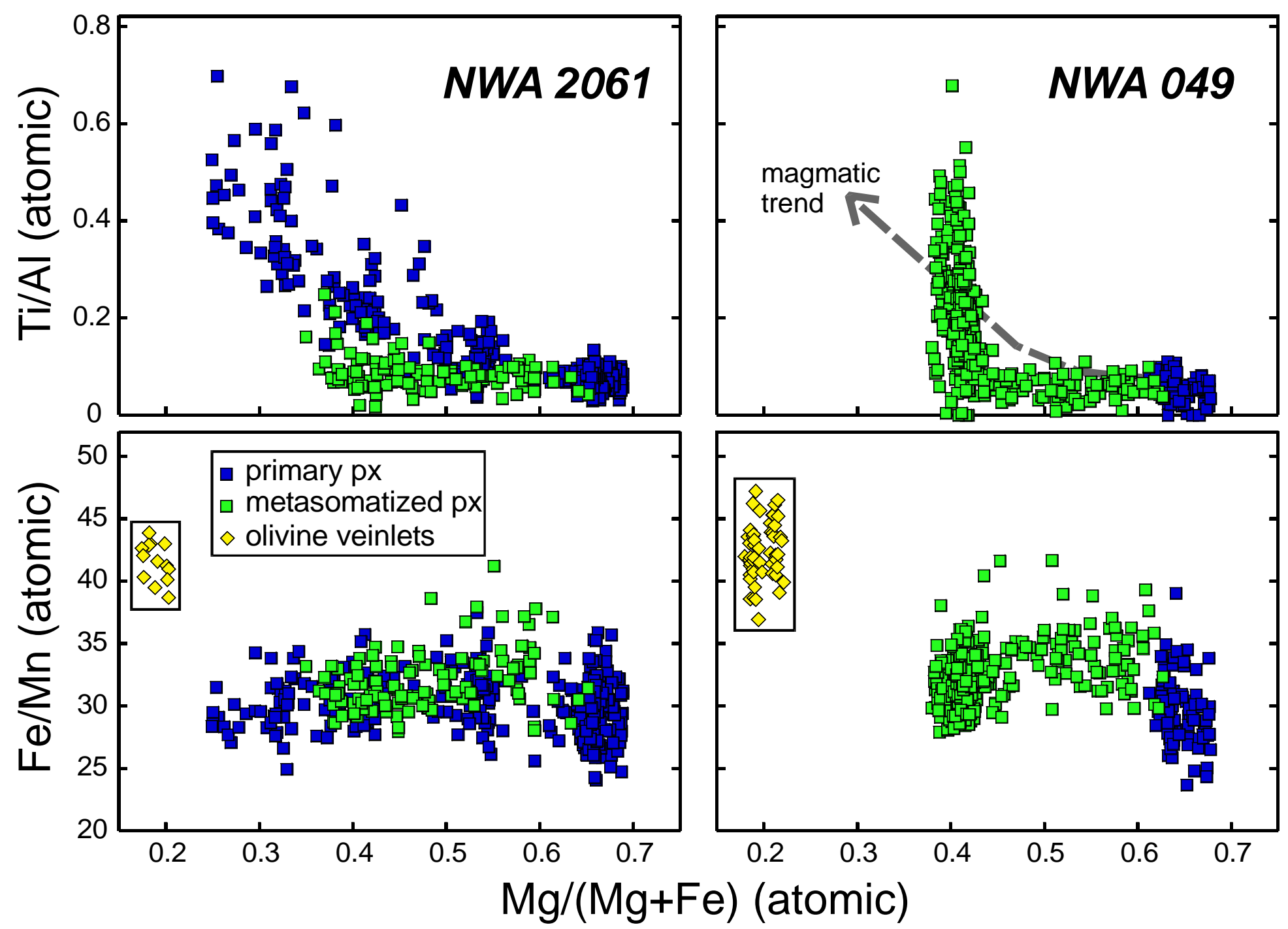

7. Ti/Al and $\mathrm{Fe} / \mathrm{Mn}$ vs. $\mathrm{Mg} /(\mathrm{Mg}+\mathrm{Fe})$ plots for pyroxenes and olivines from NWA 2061 and NWA 049. 


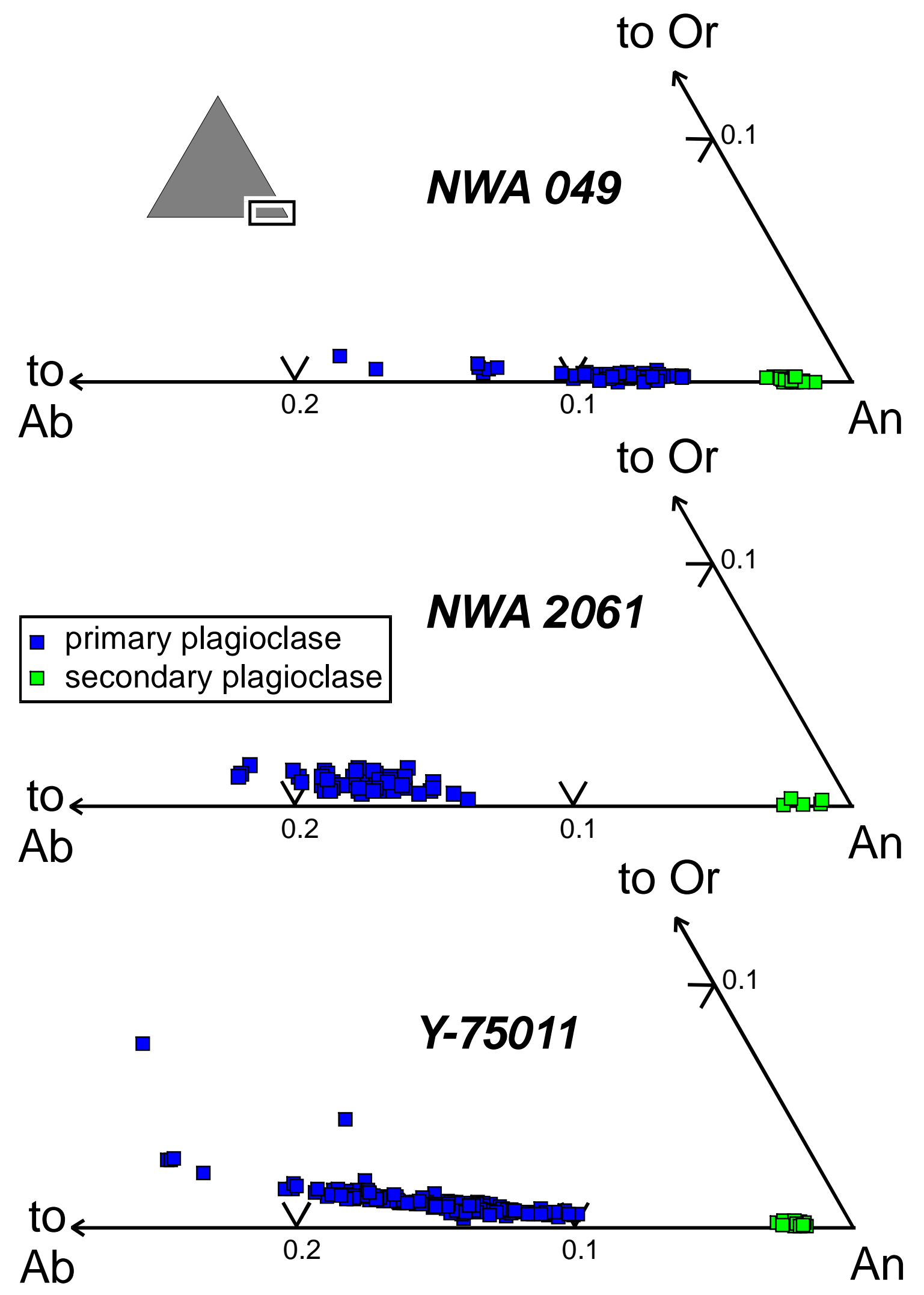

8. Compositions of plagioclases from NWA 049, NWA 2061 and Y-75011. 

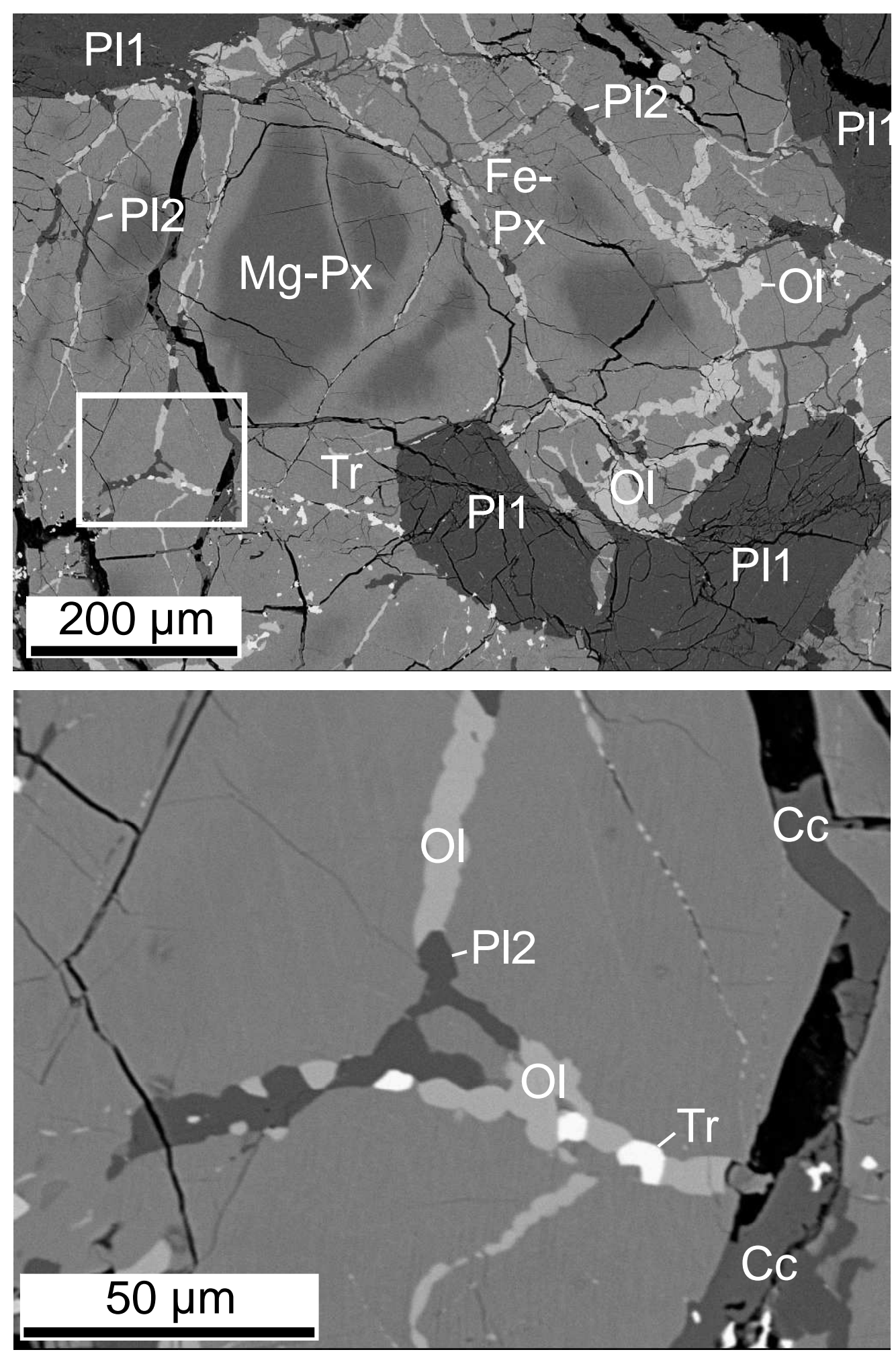

9. Backscattered electron images of NWA 049 (Cc: calcite (terrestrial weathering), Ol: olivine, P11: primary plagioclase, PL2: secondary plagioclase, Mg-Px: pristine pyroxene area, Fe-Px: Fe-rich secondary pyroxene (chiefly Al-poor type), Tr: troilite). 

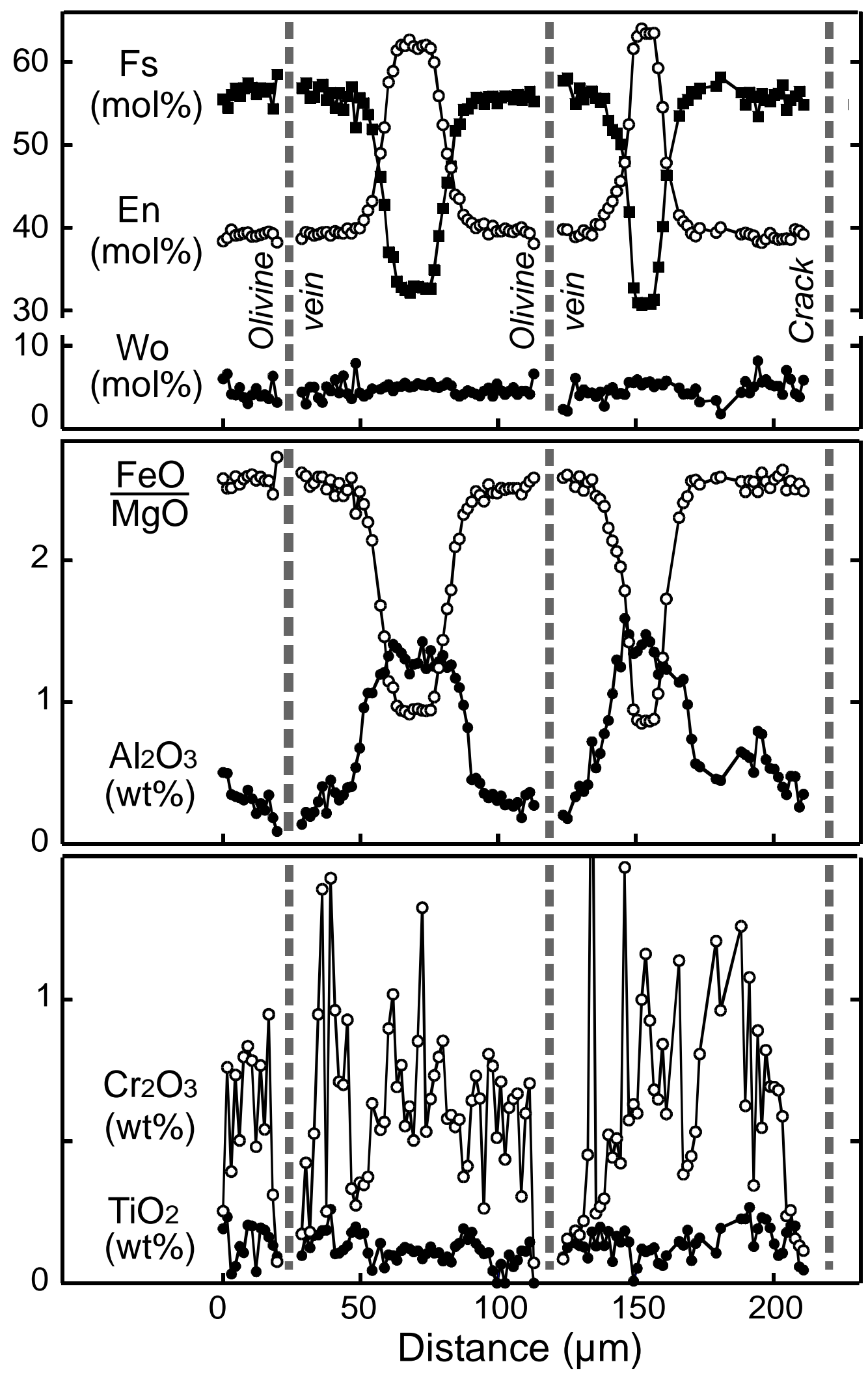

10. Chemical zoning of a pyroxene from NWA 049, displaying cracks with Fe-enrichment, and olivine veinlets. 


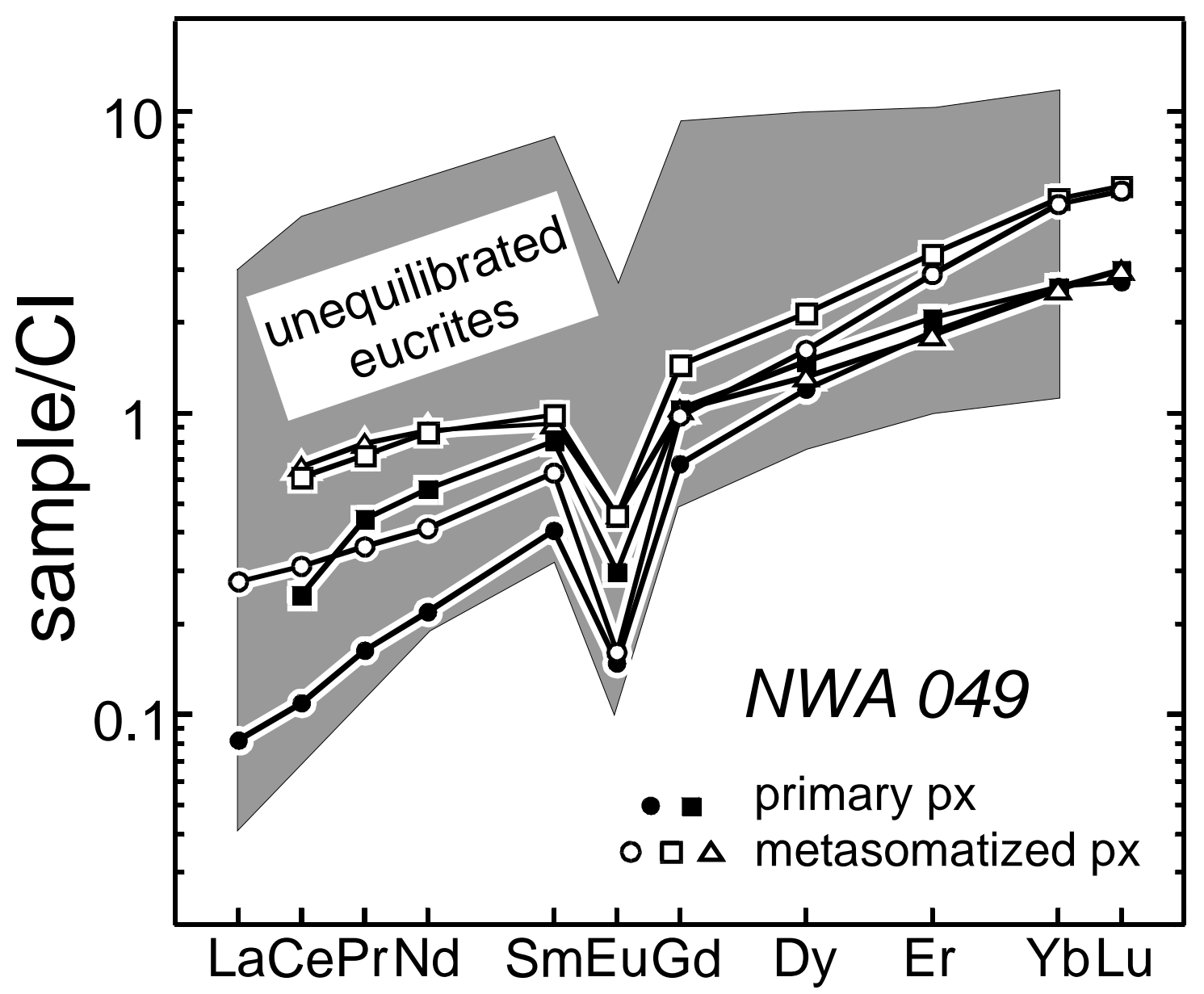

11. REE patterns of pyroxenes from NWA 049. Pyroxenes from unequilibrated eucrites are taken from Pun and Papike (1996). 

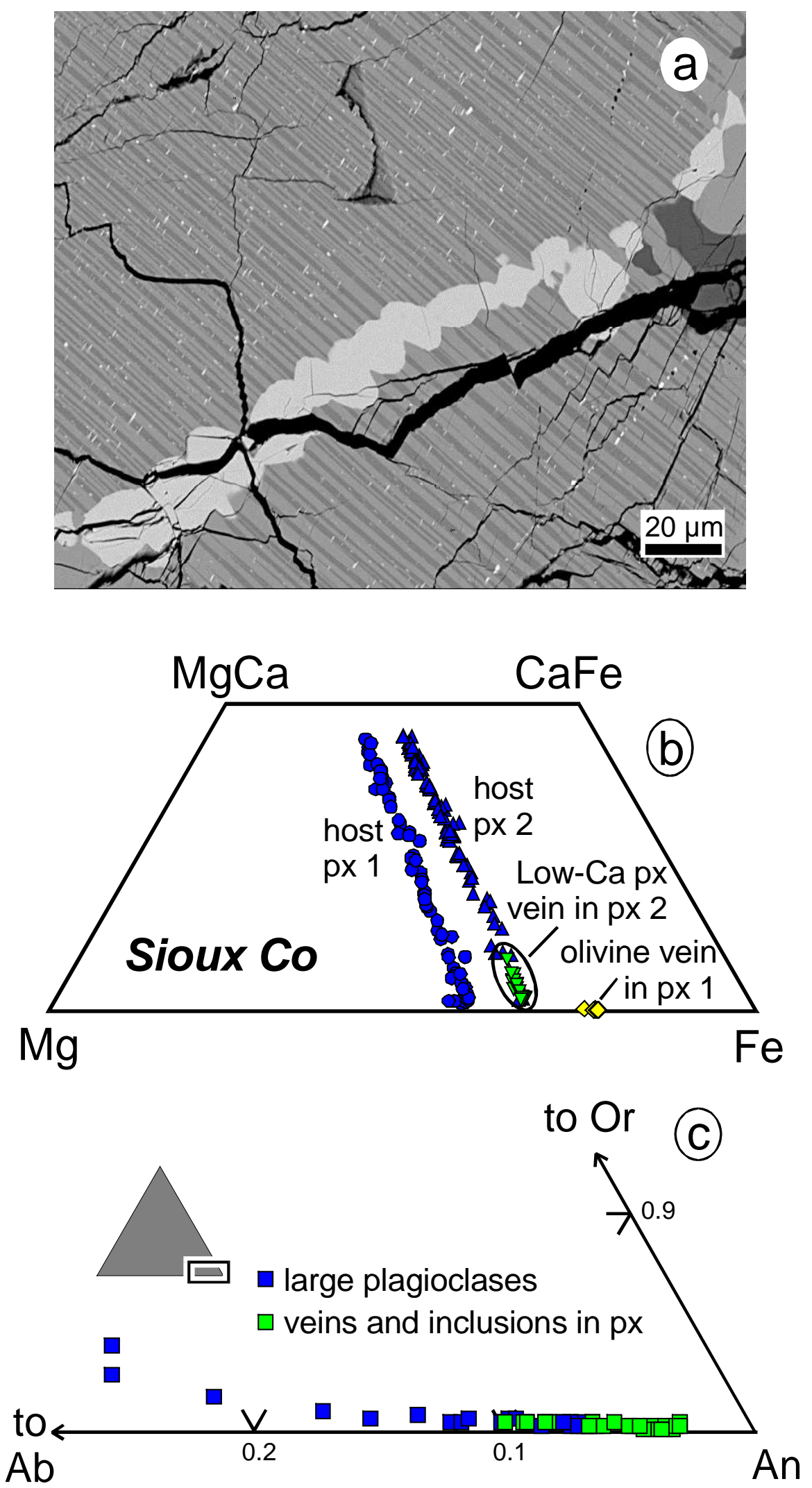

12. Sioux County. a: Backscattered electron image an equilibrated pyroxene displaying an olivine veinlet. b: Quadrilateral pyroxene and olivine compositions from two clasts. c: Compositions of plagioclases. 


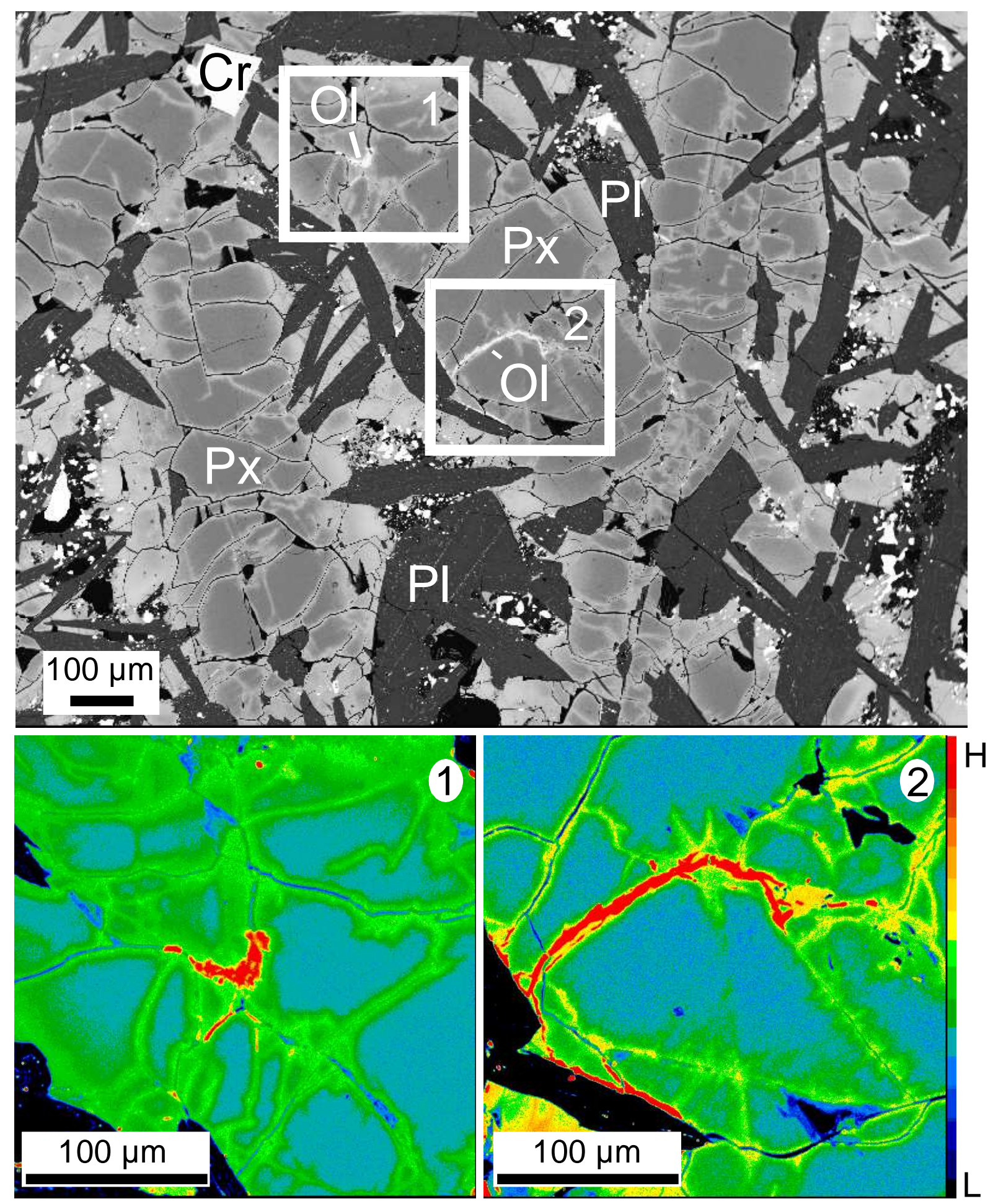

Supplementary figure 1. Backscattered electron image of Pasamonte and maps of Fe of two selected areas displaying Fe-enrichment along the fractures in pyroxenes. Olivine appears red in the maps. 

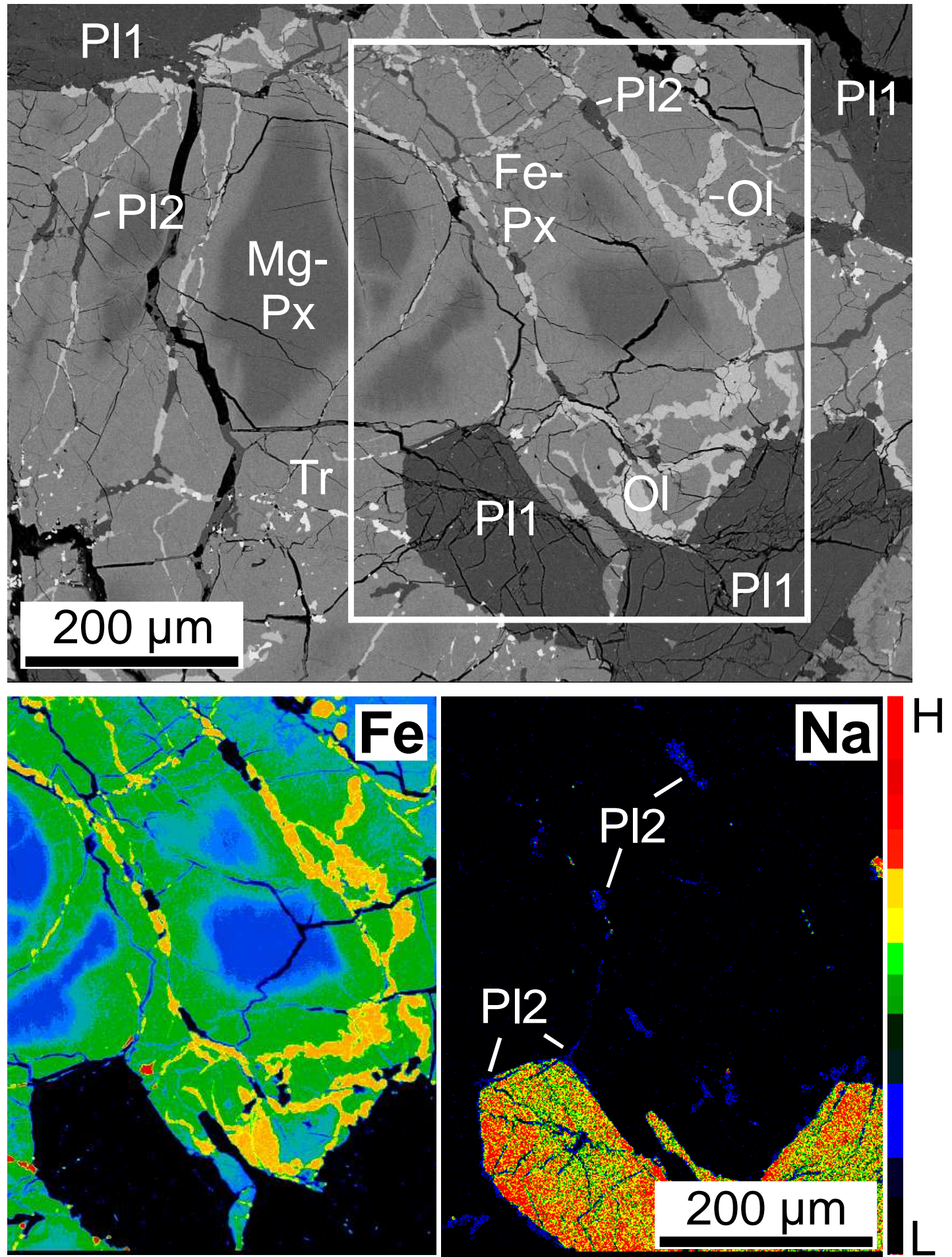

Supplementary figure 2. Backscattered electron image of NWA 049 and maps of Fe and Na. Notice the secondary plagioclase veinlets (blue) in the map of $\mathrm{Na}$. 